\title{
A Conceptual Framework for Determinants of E-Exporting (Marketing Applications) Practices and the Business Performance: Empirical Study
}

\author{
Hani Hamed Al-Dmour ${ }^{1}$ \\ ${ }^{1}$ Department of Marketing, School of Business, The University of Jordan, Amman, Jordan \\ Correspondence: Hani Hamed Al-Dmour, Department of Marketing, School of Business, The University of \\ Jordan, Amman, Jordan. E-mail: Dmourh@ju.edu.jo
}

Received: March 25, 2018 Accepted: September 20, 2018 Online Published: October 29, 2018

doi:10.5539/mas.v12n11p358

URL: https://doi.org/10.5539/mas.v12n11p358

\begin{abstract}
This research aims at identifying the determinants of the adoption of e-exporting marketing applications by Jordanian companies and their influence on their exporting performance. For this purpose, a conceptual framework based on the analysis of the literature review and the theoretical adoption models was developed. The required data was gathered through self-administrated questionnaire from 163 exporting industrial companies. The results showed that the extent of e-exporting applications being practiced is considered to be satisfactory (i.e. $62 \%$ ) and they were varied among exporting companies in terms of their size and experience. The results of factor analysis (FA) indicated that 30 determinants variables could be grouped into three major factors: organizational, environmental and technological and they could explain $76 \%$ of the variation of e-exporting applications being implemented and $83 \%$ the variation on exporting performance. Furthermore, the results have shown that organizational factor was the most important one determining the extent e-exporting applications being implemented and the environmental factor was the most important one determining the exporting performance. These resultsprovide empirical evidence that the integration approach of the adoption model could produce better explanation of the variation on both the level of e-exporting applications being practised and the business performance. In the final section, research implications and future directions are presented.
\end{abstract}

Keywords: e-exporting, applications practices, business performance

\section{Introduction}

The use of internet applications for exporting activities by business companies around the world is increasing nowadays. The internet is not only another alternative a channel of distribution to reach the customers in international markets, but it is a vital channel to find new customers as well as an appropriate tool to build and maintain long relationships with current customers. In the world, it is nonsense for business and consumers to deny the use of such new technology in their daily life (Zhang and Okoroafor, 2013; Aldmour et al., 2017). Given the competitive advantage of the use of internet applications for exporting activities, it has been received great attention from several researchers over the world for several years. These studies have reported that when deployed by exporting companies, e-exporting can be beneficial by: improving customer service in foreign markets; easing the management of supply chain activities; enhancing inventory control; extending market coverage; and reducing both marketing and distribution expenses (Bianchi and Mathews; 2011, 2013).

In comparing with the conventional mode of entry market approach, the use of the internet for exporting activities helps exporters to enter foreign market without any geographical barriers as well as itallowsto them to establish instantly virtual branches throughout the world. Morgan-Thomas and Bridgewater (2004) indicated that because of the lack of alternative channels to foreign markets, the less experienced exporters might rely on technology to a much greater extent, in that way; they may generate greater benefits as they are more proactive in adopting new technologies and especially internet. Furthermore, it is argued that the use of internet for export marketing activities will improve the relationship between customers and exporters. Using internetas a none conventional channel could provideopportunities for exporters such as: a new and lower-cost channel to foreign market, better knowledge of consumer preferences; and offer a wide choice of products and service.As indicated by Rosson (2004), manufacturing companies and particularly SMEs, can utilize the Internet to enhance their 
export orientations in three different ways: (I) as a worldwide promotional tool, (2) as an effective low-costing channel of distribution, and (3) as a tool for customer service. Moreover, the connivance, utilization of the Internet has the capability of overcoming some of the serious long-term problems associated with exporting. The major exporting problems that the use of Internet canminimize or eliminate are the following: data obtaining (concerning potential foreign customers and their shopping habits, type of competitors, suppliers and foreign market conditions), export paperwork, documentation, inappropriate foreign intermediateand agencies, access to internationalmarkets, access to international promotion and communicationtools with foreign customers, , the costs and risks associated with the above functions, (Hajidimitriou and Azaria, 2006).The major issues that potential exporting companies usually face in the new international markets are: absence of security, lack of lack of protection of the intellectual property, lack of privacy, lack of censorship, lack of standardized international law, cultural diversity (such as several foreign languages, distinctive perception of figures, colors, pictures and motions), telecommunication infrastructures PCs' accessibility, the different popularity of Visa use crosswise over countries (Melewar and Smith, 2003), the limited target of audience since websites can be accessed by any person on the Internet, the intense competition created by the presence of thousands of different homepages, which are all attemptingto draw attention and maintain visitors, the presence of choice for Internet clients (the client should effectively choose to visit the site), unlike radio and TV, the presence of high cost for regular clients, and the availability (Zhang and Okoroafor, 2013; Al-Dmour et al., 2019).

Internet-based market structures and, all the more extensively, the expansion of worldwide media telecommunication systems seems to offer manufacturing companies in developing countries new trade tools that will empower them to compete on a more equal basis in the foreign markets. Furthermore, the wider applications of internet in the business context have increased intensively, many companies in developing countries like Jordan could use internet as a mechanism to overcome such export-marketing barriers. In fact, the explosion of export marketing activity on the Internet has provided a fundamentally different conditions and opportunities for international marketing (Eid and Trueman, 2002). Not just has the marketing mix elements and the adopted marketing strategies been dramatically changed (Strauss and Frost, 2002; Masa'deh et al., 2018), the productivity of conventional marketing activities has also expanded. The Internet serves as a tool that suits the process of doing export business or a tool conveyed for promotion, information, and export income enhancement (Farhoomand and Lovelock, 2001; Obeidat et al., 2017).

The interest in this research has been guided mainly by a basic assumption that e-exporting is one of the tools which will enable companies to improve their operations in foreign markets. It is also proposed in this research that the adoption and use of e-exporting should focus on diverse contexts such as factors of influence and appropriate theoretical models. In the case of Jordan, the study of e-exporting adoption and use by exporting companies is still in an early stage. The previous studies indicated that the use of the Internet helps companies to export effectively to any market of the world, regardless of the level of economic and infrastructure development, culture diversely and business practices of the export market. However, the available studies provide a little empirical evidence of a relationship between the practice of e-exporting applications and export performance. For example, Avlonitis and Karayanni (2000) and Prasad et al. (2001) reveal an indirect impact of the use of Internet upon the company's export performance whether by means of its integration into the company's marketing technology or through sales management tasks. Therefore, there is still a lack of systematic empirical findings with respect to the importance of the practice of internet Vis-a'-Vis the export marketing activities and the company's export performance. Furthermore, because of the majority of research on e-exporting adoption has been undertaken in the developed countries (Kula andTatotglu, 2003, Shankar and Meyer, 2009), the extent to which research findings in these countries can be extended to the Jordanian context should be examined since there was no study has done before in Jordan for this purpose.

Besides, Study's findings indicated that Internet research executed in developed countries may not be helpful and generalized in Middle East countries due to differing cultural issues (Gong, 2009; Grandón, et al., 2011; Nasco, et al., 2008). This is in consistent with a recent call for more research on developing countries such as Eastern Europe, Middle East and Latin America, and well as on the practice of internet in international marketing (Leonidou and Barnes, 2010). Consequently, given the role of exporting to a country's economy and the expanding use of the Internet in business functions, constituting a study that investigates the impact that the practice of the Internet may have on export market growth for Middle East companies is viewed as convenient. Several researches have been conducted intensively in Australia (Mathews, et al., 2012), the USA (Samiee, 1998), and Europe (Moen et al., 2008), Latin America, (Bianchi and Mathews, 2011, 2013). Certainly little evidence has been found to suggest that cultural differences exist in terms of acceptance of modern communication technologies by firms in Middle East developing countries (Wresch, 2003).For example, Middle 
East countries are considered to be high context, collectivist culture, with high uncertainty avoidance (Hofstede, 2011; Shannak and Obeidat, 2012). In terms of Internet marketing, this may mean that managers may perceive this activity as an impersonal way to do business internationally and prefer to gain market information from personal information sources (Grandón et al., 2011).

Therefore, the purpose of this study is based upon identifying the determinants of the adoption of e-exporting applications by Jordanian companies. It is very important for more than one reason. First, it provides some insights into the implementation of e-exporting activities by Jordanian exportingcompanies, which should help exporting practitioners, acquire a better understanding of the current status, benefits, and barriers to the implementation of e-exporting. Second, exporting managers should be informed about the extent of e-exporting implementation by Jordanian companies as an alternative channel strategy for doing business abroad through internet, and third, it is expected that findings from this study will provide more guidelines for the implementation of e-exporting framework and their effective use thereby improving the country economy.

\subsection{Research Objectives}

The main aim of the current research is to identify a comprehensive set of potential determinants of the use of e-exporting marketing activities by Jordanian industrial exporting companies and their influence upon their business performance (financial and non-financial). The specific objectives of this study are:

1. To develop a conceptual framework through the integration of several relevant studies in this area, in which will incorporate the determinants of e-exporting practices by the exporting industrial companies in Jordan, and to empirically examine, validate and predict the viability of this proposed conceptual framework.

2. To derive a number of distinct factors that are likely to affect the use of e-exporting applications.

3. To explore the nature of the relationship between each of the derived factors and the resultant extent of the use of e-exporting applications.

4. To evaluate which of the derived factors is most influential in determining the resultant extent of the use of e-exporting applications and its influence on the exporting performance.

The above objectives can be translated into the following research questions:

1. What is the extent of the use e-exporting applications by Jordanian exporting companies?

2. What are the direction and the strength of the relationship between the extent of the use of e-exporting applications and the e- exporting performance?

\subsection{The Importance of E-Exporting to Jordan}

Export activity plays a significant role at the national and company levels. At the national level, export activity is important because it contributes to the economic development of nations (Al-Dmour and Brandki, 2008). It influences the level of imports a country can afford and the amount of foreign exchange reserves, while forming public image of national competitiveness. Additionally, exports improve community prosperity and enhance economic national development. Abroad, exports increase consumers' power of purchasing, quality oflife and improve the standard of living (Lages and Montgomery, 2004;Kontinen and Ojala, 2010). Jordan's economy is heavily dependent on its export sector as a mechanism of growth within an increasingly competitive global economy. The Jordanian export sector is generally categorized into the commodities and non-commodities exporters sectors.

The commodities export sector is made up of clothing, fertilizers, potash, phosphates, vegetables, pharmaceuticals. The non-commodities export sector comprises all other exports from Jordan aside of these commodities include tourism, banking, education, information technology and labor services. Statistics from government show that export generated in real values: $\$ 9.614$ billion in 2016 . With the continuous spread of the internet and its related applications worldwide, and despite the importance of the export sector and the impact IT could have on Jordanian export firms, there is little evidence about whether these firms in this sector are benefiting from the internet applications for exciting exporting activities. This study is therefore, designed to explore to which extent the Jordanian companies use the internet for the exporting purposes and its impact on their export performance.

\subsection{The Significance of the Study}

The major potential contributions of the present study could be summarized in the following points: 
1. To the best knowledge of the researcher, this study could be the first attempt undertaken in the Jordanian environment to measure and validate the determinants of the practice of e-exporting applications at the level of organization.

2. A conceptual framework was proposed for the factors that determine the organization's level of practice of e-exporting applications and measuring its influence upon exporting performance. This framework integrates ideas and elements from Technology-organization-environment model and the e-commerce studies in the area of international marketing.

3. It has been shown in the literature; the body of the research on the e-exporting is heavily oriented to the companies in developed countries. This research will extend its scope to include less-developed countries (LDS) like Jordan.

\section{Theoretical Background and Literature Review}

\subsection{E-exporting: Importance and Applications}

Rodgers, et al. (2005) indicated that the Internet has been recognized as one of the most important marketing medium in the international marketplace for its large potential use for businesses. Recent studies emphases that the Internet can help exporters by improving access to foreign markets, increasing the level of internationalization, and minimizing logistics costs and risks (Zhang and Okoroafor, 2013; Kontinen and Ojala, 2010), as well as enhancing communication and the effectiveness of information exchange (Mathews and Healy, 2008; Bianchi and Mathews, 2013). The Internet serves as a vehicle for the process of conducting export business as well as a tool deployed for promotion, information and export revenue enhancement (Zhang and Okoroafom, 2013). Not only do large firms with sizeable capital capabilities have the ability to export through the Internet, but small and medium companies may also do so with only moderate investment (Arnott and Bridgewater, 2002; Bianchi and Mathews, 2013). For example, from a sample of UK exporting businesses, Bennett (1997) reported that UK exporters with Web sites have positive attitudes toward the advantages of the use of Internet, particularly in areas such as collection information, reputation enhancement, cost reduction and improved sales.

In contrast, UK exporters without Web sites believe that the Internet is technically innovative and costly, and above all, they see personal contact as opposed to online contact with customers as highly valuable and credible. Also, from a sample consisted of Australian business industries. Lu and Julain (2007) concluded that when the Internet was used to achieve a competitive advantage for the firm and reduce the costs associated in doing international business these uses of the Internet were significant in discriminating between high and low export marketing performance. Furthermore, the international experience of the export venture's management was a significant factor in discriminating between high and low export marketing performance. A number of conceptual studies on the implications of the Internet for marketing suggested beneficial effects of Internet marketing on business performance, for example, a study by Bianchi and Mathews (2013) reported that Internet marketing applications significantly influence business relationships and quality and availability of informationand, which lead to an improvement in export performance level. Furthermore, the Internet offers interactivity and dynamism for the exporting firms to conduct their exporting business both effectively and efficiently.

Internet can be used to do other critical marketing functions more effectively, such as finding the right overseas suppliers, access on data and information to support export planning; online communications to support networks and so on (Zhang and Okoroafor, 2013). Accordingly, practicing of e- exporting activities are highly likely to have positive impact on the companies' business performance. Considering its innovativeness and requiring new paradigms (Evans and Wurster, 2000), adoption of Internet marketing could be viewed as an adoption of innovation. Cassimanand Golovko (2011) showed that the antecedents of an organization's innovativeness and business performance determine the learning capability of the organization. Many studies on the firms' adoption of innovation (Bianchi and Mathews, 2013) revealed a systematic and positive relationship between firms' learning and dynamic capability, innovativeness, and business performance. Internet marketing within the exporting process of the firm has been viewed as the integration function of the Internet into international marketing activities and business processes of the firm. For example, Moon and Jain (2007) show that Internet marketing research positively impacts firm's market share, sales and profit.

Mathews and Healy, (2007), also reported that the Internet has increased the amount of accessibility to foreign mart information and has minimized the perceived risks associated with doing business abroad by small and medium sized companies. Several studies point out the positive effects of the use of Internet on international 
information accessibility (Berry and Brock, 2004; Brock and Yu, 2005) which in turn minimize the perceived risk associated with export performance (Mathews and Healy, 2007; Moen et al., 2008). The Internet helps companies to collect primary data through such tools as online surveys, customer data systems, email marketing lists, web guests tracking, and promotional measurement and evaluation (Lohrke and Frownfelter-Lohrke, 2006). Sources of secondary data such as online newspapers and journals, country economic and legislation reports, individual country and industry market and lists of suppliers, distributors, agents and government body's contacts can also be obtained. The Internet can also provide a new and efficient tool for performing market research and collect the appropriate market information for making more effective marketing decisions (Teo and Choo, 2001). Internet marketing is an energetic and fast tool to reach customers and suppliers in anywhere in the world, irrespective of the country's online infrastructure (Lituchy and Rail, 2000; Roccapriore, 2000).

In addition, because of its ease of use, wide accessibility, common standards and low logistic cost and the Internet improves the integration and coordination of marketing functions by allowing staff from different departments within the company to share and exchange information and communicate with their customers and suppliers better (Afuah, 2003; Jean, et al., 2010), and enhance global relationship performances for the company (Jean and Sinkovics, 2010). As indicated by Loane and Bell (2006) company should not only emphasis on resources per se but where capabilities through relationships connect its specific resources to exploit international opportunity. Thus, the Internet is essentially important for improving the company's existing customer and supplier base and for the company's capability to build and keep strong business relationships with customers and suppliers in foreign markets. Relationships and social media network building and maintaining capabilities were found to have significant impact on company's performance in a domestic and foreign market (Morgan-Thomas, 2009; Musteen and Datta, 2010). Loane and Bell (2006) argue that business networks are valuable assets for Internet enabled small companies in their internationalization endeavors. An international network outlook determines the role of cooperative activities and relationships in international market development (Dimitratos and Dana, 2003).

\subsection{Determinants of the Use of E-Exporting}

Several studies have examined the adoption of use of e-commerce for several reasons in the past. In this study, the review is mainly limited to the adoption and success of using e-exporting. Although the exporting through internet is increasingly being used worldwide, little theoretical and conceptual framework research examining the antecedents of e-exporting adoption and use is available. Furthermore, these studies do not provide a full -perspective of the factors influencing the adoption of the e-exporting and its contributions to company's export performance. In 1977, Bennett has attempted with small size sample form British exporting companies to identify the main factors of whether firms would or would not be Web-owners with an export orientation.He examined whether the exporting firm's characteristics determine its ability to operate a Website. A survey of the characteristics of exporting firms that possess sites on the World Wide Web was administered. The study's findings showed substantial differences between companies with Web-sites and those were not in the following areas: typical number of years in exporting; whether firms employed foreign agents or other local representatives; and respondents' evaluation of their levels of IT expertise and knowledge within their firms. In 1997, Poon and Swatman (1997) examined the preconditions-factors for Internet success by a sample of 23 SMEs around Australia, and the strategic outcomes from its use. The findings identified six general factors of successful Internet use: the type of internet application, management willingness in promoting Internet use, perceived advantages from Internet use, the characteristics of industry and product, the availability of Internet-to Internal systems integration, and the availability of IT expertise.

Another approach on the subject of factors influencing the successful use of the Internet for exporting purposes was attempted by Samiee (1998). The findings of his study identified nine general factors that would probablyaffect the use of Internet in export markets:the type of internet application type (as a medium for business process automation or as medium for revenue generation), exporter type and its development stage (e.g. sporadic and regular exporter, or non-exporter and active exporter), transaction type (intrafirm or interfirm exporting agreements and exchanges), computer literacy, access to Internet network, availability of equipment for access and for servers as well as penetration of personal computers, limited regulations about accessing and penetration of the Internet, language, and culture. The last six factors were classified and labeled as a structural constraints and environmental factors. Despite the importance of Samiees' suggestions, the weakness is clear. The approach is totally theoretical and there is no empirical evidence or practical applications for his guiding principles. Also, Samiee (1998) investigated the Internet's problems and roles in export marketing. He identified two types of obstacles to the Internet's adoption and success in international marketing: structural and functional. Structural problems related to the nations' information infrastructures, as well as their languages, cultures, and 
legal framework. Functional problems include marketing program and logistics issues, including data management and customer content.

Moodley (2002) identified four major factors of successful Internet use in exporting and expansion into new foreign markets: level of awareness of e-commerce, the number of year in exporting (experience), the exporting type and stage of internationalization, the availability of IT expertise, and the level of technical infrastructure.Morgan-Thomas and Bridgewater (2004) have also identified eight significant factors affecting successful Internet use of 705 British exporters with corporate Web sites, These factors were: exporter type, exporter experience, product specifications, level of Internet experience, the level of Internet usage by other stakeholders in the same market (Network Effect), level of investment in Internet development and implementation, , sophisticated use of Internet (how the Internet is used), and existing channel structures (having its own export sales force). Song (2004) explored the factors influencing the small and medium-sized exporting firms' intention to use the Internet as exporting marketing activities (information gathering, supports, and transactions). He conducted an empirical study based on a conceptual model including product, organizational, and industry characteristics. The study did not examine exporting firms' actual Internet marketing activities, but only their related intentions.A study by Moon and Jain (2007) revealed that those characteristics of the firm, product, channel and environment influence the degree of international Internet marketing activities of exporting firms. Moreover, the results also demonstrate that international Internet marketing activities of exporting firms influence their business performance.

Next, Azaria (2010) conducted a research on the specific subject of identifying the factors affecting successful Internet use for exporting purposes by Greek SMEs. The detailed review of the respective literature yielded a list of 20 possible success factors of Internet use for exporting activities (Azaria, 2010). In order to test the validity of those factors, Azaria (2010) conducted an empirical research on a sample of 80 Greek SMEs from all over Greece. The results revealed that 8 out of the 20 possible factors have a significant influence on the successful Internet use for exporting purposes. These 8 factors are (Azaria, 2010): a) the level of investment in Internet development and implementation, b) the technological infrastructure of the company, c) the security of business transactions on the Internet, d) management enthusiasm in promoting Internet use, e) the characteristics and the specificity of the product, f) exporter type (sporadic or regular), g) the level of Internet usage by other stakeholders in the same market (Network Effect), and h) the number of languages in which the firm's corporate website is translated into. Houdeloudi (2013) revealed that there are 4 important factors that appear to have a significant influence on the successful Internet use for exporting activities: a) management's willingness in promoting Internet use, b) the level of investment in Internet development and implementation, c) the level of Internet usage by customers, competitors and suppliers in the same market (Network Effect), and d) the need of foreign customers for a personal contact with the sales person of the exporting company.

Ueasangkomsatea (2015) conducted a study aiming to examine small and medium companies (SMEs) in Thailand to e-commerce adoption for export market. The findings showed SME's awareness between exporter and non-exporter and also different size of SME exporters toward the advantages of e-commerce to export market being as the same at the high level. His study also demonstrated the relationship between SME exporter and the level of e-commerce adoption which is dependent positively. In addition, this research concluded that e-commerce adoption of Thai SME exporters does not impact positively to export growth significantly.

\subsection{Export Performance}

Export performance can broadly be defined as the outcome of a firm's activities in export markets (Edwards, et al., 2018). Mysen (2013) define it as the firm's degree of economic achievement in its export markets. Whereas there is a growing body of literature regarding export performance, its conceptualization and subsequent operationalisation has remained a thorny issue in exporting literature (Mysen, 2013). Consequently, several conceptual contributions have appeared seeking to come up with dimensions and measures of export performance. Kosan and Kabuya (2014) have identified that export intensity, export sales growth, export profit level, export sales volume, market share, and export profit contribution are mostly used measures of export performance. Kosan and Kabuya (2014) observe that export performance of a firm can be measured by using subjective and objective measures since research shows that both yield consistent results. They noted that objective measures are concerned with absolute performance indicators whereas subjective are concerned with performance of a business in relation to its major competitors or relative to a company's expectations. From these submissions, it can be deduced that export performance is a multi-dimensional concept comprising of a firm's international sales, market share, profitability, growth and export intensity in relation to its competitors.

However, it should be noted that empirical researches that examine the effects of e-exporting applications 
utilization on export performance are limited and emphasize that e-export might improve export performance. Ayan and Percin (2005) and Kosan and Kabuya(2014) reported this may be perceived by making it easier for firms to communicate well with foreign customers and suppliers, minimizing the costs of international promotion, paperwork,transportation and product design, by enhancing access to international market information and improving entry to foreign markets. As to measure the impact of e-exporting on the export performance in this study, multidimensional measures were used: subjective and objectives. Seven itemswere introduced based on the respondent's idea or perceptions and measured on 5-point Likert scale (strongly disagree to strongly agree) are "Online exporting has significantly improved our export profits", "Online exportinghas significantly improved our export sales volume", "Online exportinghas significantly improved our export market share" and "Online exporting has significantly improved our overall performance. Online exporting has significantly improved our overall image and reputation, "Online exporting has significantly improved our customer's satisfaction. In addition, three other objectives measures are included and measured in ordinal scale: percentages of profits generated by e-exporting, percentage of export sales generated from e-exporting, and percentage of export growth generated from e-exporting.

\section{The Stud's Conceptual Framework}

Much of the research on the role of internet in international marketing and business activities were exploratory in nature, employing a variety of approaches and theoretical frameworks (Biswas and Krishnan 2004; Shankar and Meyer, 2009; Czinkota and Ronkainen, 2018). The research of IT innovation and adoption in general and e-commerce in particular by business firms were applied several theoretical models for different purposes, such as Technology Acceptance Model (TAM); Adoption, Innovation, and Diffusion Theory (Rogers, 1995); Unified Theory of Acceptance and Use of Technology (UTAUT). These models when applied in quantitative studies commonly us factors which influence adoption either positively or negative, however, few studies have been devoted to the potential use of Internet in exporting (e.g, Rosson, 2004; Azaria, 2010; Houdeloudi, 2013).

Most frequently, these factors are identified in previous studies in IT adoption as either incentives (also referred to in the literature as drivers, determinants, motivators) or barriers (inhibitors) to adoption and use. Researchers have clustered these factors in different ways. In this study by following the technology, organizational, and environmental (TOE) framework developed by Tornatzky and Fleischer (1990), these factors are grouped into environmental, technological and organizational. Previous studies have also used this framework in the context of IT adoption (e.g. Ramdani and Kawalek, 2007; Al-Dmour, et al., 2013, 2015, 2016). These studies are important and significant for the purpose of this study because they theoretically and empirically identify a number of variables affecting IT and e-exporting. The relationships of these factors/variables with the adoption of e-exporting are shown in Figure 1.

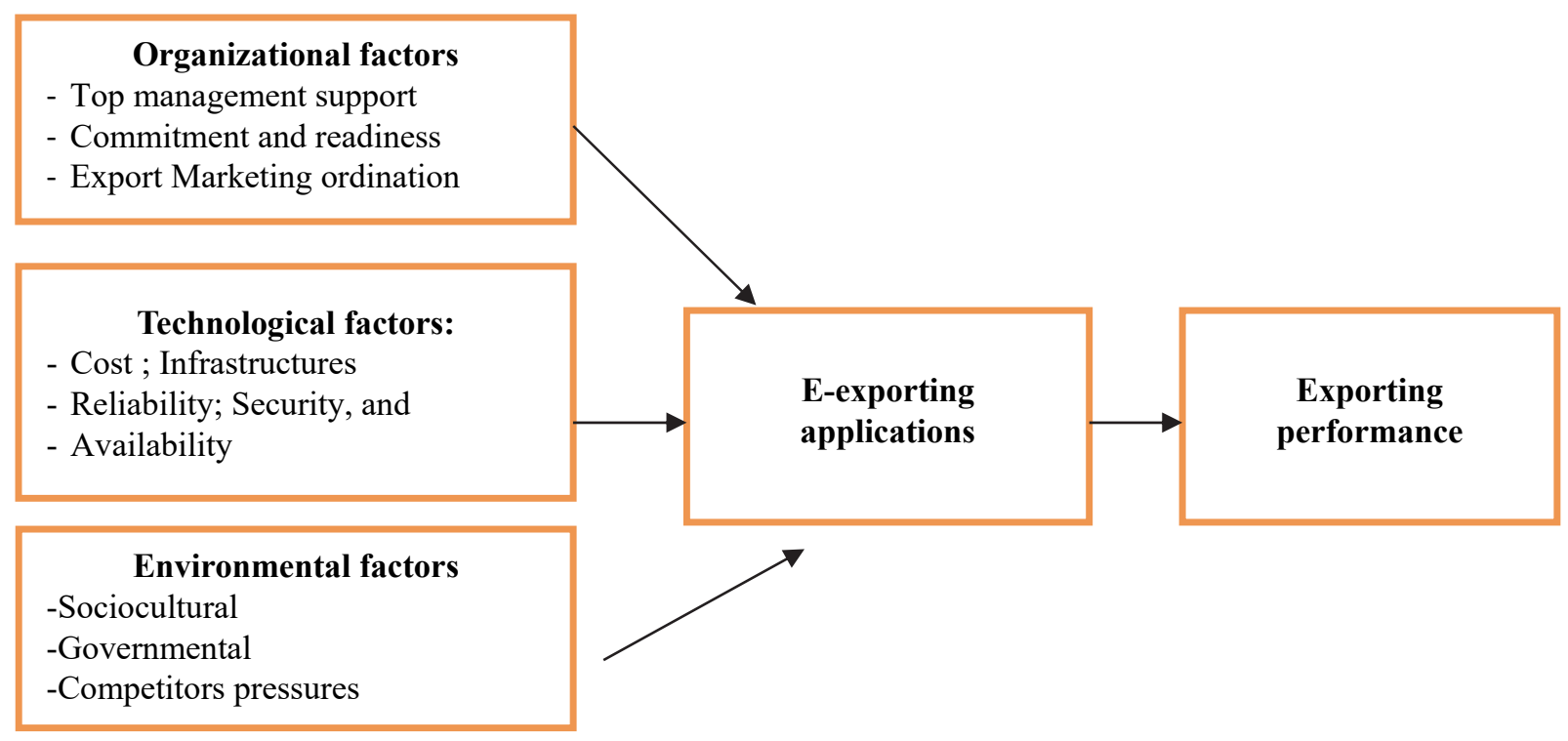

Figure 1. Research model 
Organizational Factors: The first cluster of variables is called organizational factors that relate directly to availability and use of internal resources.

Top Management Support: previous studies indicated that the top management support play an important factor in the adoption and implementation of IT (Liao and Tesng, 2010; Tarhini et al., 2015). For example, Jeyaraj et al. (2006) surveyed 51 studies on organizational information technology (IT) adoption published between 1992 and 2003 and found top management support was a positive impact on IT adoption. It is vital for building a supportive climate and providing adequate resources for the adoption and implementation of new innovations (Al-Dmour et al., 2016). According to Al-Dmour et al. (2013), top management with their broader perspective, would be able to identify business opportunities for the use of information technology and their active enragement and support would help to develop appropriate goals and strategic direction for the adoption and implementation of new innovations or technologies. Fillis et al. (2004) also reported that there are differences in attitude towards embracing Internet and e-business in different companies because of core owner/manager factors (Fillis et al. 2004). Two of these factors, which are very important, are the following: a) management's enthusiasm and b) management's level of entrepreneurship. Management's "laager" mentality, which has locked several companies into an insular, inwardly oriented way of thinking, can be a great obstacle to the diffusion and adoption of Internet use for exporting purposes (Moodley 2002). Research suggests that companies with owners or managers being proactive and eager to adopt and promote Internet use for exporting purposes, are more likely to perform better results in their performance (Rosson, 2004). Houdeloudi (2013) also mentioned that the successful Internet use for exporting activities were significantly influenced by management's enthusiasm, the level of investment in Internet development and implementation, the level of Internet usage by other stakeholders in the same market, and the need of foreign customers for a personal contact with the key persons of the exporting company. Companies with a creative organizational culture are likely to adopt new technology and innovations eagerly. Deshpande et al. (1993) conceptualized that organizational creativity/ novelty is an attitudinal trait of the key decision- makers of firms that resides in their culture, or shared values and beliefs. Damanpour and Schneider (2009) showed that managerial attitudes toward change were positively related to radical product innovation and they illustrated that the stronger is a firm's willingness to write off research investments made in the past, the higher is the possibility of radical product innovation.

Organizational Commitment and Readiness: Exporters differ in their levels of commitment to the new technology. Commitment may be financial, but may also involve the time spent training and time spent on supporting Internet adoption. In order to set up and run a successful corporate website, companies need several investments that include financial resources for: i) the development and implementation of the website, ii) covering running costs, maintenance and upgrading, and iii) acquisition and training of the staff that coordinates the integration of the Internet with existing marketing processes (Morgan-Thomas and Bridgewater, 2004). Hence, the literature hypothesizes that there is a link between resource commitment to the Internet and the success of its implementation for exporting purposes. Organizational readiness refers to the level of human, economic, financial, business and technical resources of the firm (Al-Dmour et al., 2013). Zhu and Kraemer (2005) mentioned that organizational readiness includes infrastructure, relevant systems, and technical skills. Although, the definition of organizational readiness differs in the literature, all authors are agreed that organizational readiness has a strong influence on the adoption of organizational technologies. Organization readiness is also important from a resource perspective. As the implementation of e-exporting project is a long term process for companies as they have to continually increase their level involvement, and continually increase the number of distributors or customers in the involvement. E-exporting is also a technology that requires an organization to plan, commit and execute according to the needs and expectations of the foreign markets. As such, it requires evaluating top management's support, financial and technical feasibility (Al-Qirim, 2004). Several research studies also revealed that the level of IT and Internet knowledge and experience within a firm had a significant impact on the Internet adoption (Muriithi, 2016). In addition, it is suggested that the successful use of Internet and e-commerce as a strategy for expansion into new markets is likely to be influenced by factors such as the technical infrastructure and the availability of IT literate personnel (Moodley, 2002).

The business's size and business experience are also found to have a significant influence on the adoption of IT (Al-Dmour et al., 2013; Matta and Moberg, 2006; Liao and Tesng, 2010). Camison-Zornoza et al. (2004) confirmed the existence of a significant and positive correlation between firm's size and innovation. Furthermore, it would appear reasonable to suppose that larger business have more potential to use information technology that small business does, simply because of their larger scale of operations. However, past studies suggest that firms with less exporting experience are likely to be more eager to execute international Internet marketing activities. For example, Song (2004) construed: "It appears that firms relatively new to exporting were 
establishing websites more eagerly than companies with well-established international marketing systems. Inexperienced exporters are perhaps unencumbered with pre-existing assumptions about how export marketing ought to be managed." Morgan-Thomas and Bridgewater (2004) showed that firms with little export experience gain more from the use of Internet export channels than do firms with high levels of export experiencerecommends that market introduction exercises help weaken merchant advantage caused by data asymmetry. In worldwide markets without online business, data asymmetry wins as exporters have a tendency to have less data about clients and rivals in remote markets than wholesalers.

Export Market Orientation: Chung (2012) has identified market orientation as the "organization-wide generation of market intelligence pertaining to current and future customer needs, dissemination of the information across departments, and organization-wide responsiveness to it". From this definition, it can be realized that the adoption of market orientation can possibly enable an organization to respond and meet customers' needs and requirements successfully. When it comes to exporting firms, some researchers suggest that with export market orientation, exporting firms continually identify and meet customers' needs and expectations, competitors' new marketing strategies, and environmental changes international markets (Ju et al., 2011). As indicated by these researchers (Ju et al., 2011), suggests that market orientation activities help weaken distributor advantage caused by information asymmetry. In worldwide markets without e-commerce, information asymmetry happens as exporters have a tendency to have less information about customers and competitors in international markets than agents. Gebhardt et al. (2006) argue that developing a market orientation needs a systematic change to an organization's values and culture and the development of organizationally shared market understandings. In addition, some empirical studies indicate that there is a significant relationship between market orientation and export performance (Armario et al., 2008). Although these investigations do not examine the relationship in e-commerce context, there won't be much contrast. As a stage, e-commerce system can encourage the information sharing among exporters and foreign distributors to support or strengthen market orientation. The current study considers the following organizational factors: top management support and commitment, availability of human IT resource (Technical Expertise), financial capabilities, management support, and Company's export experience and size and market orientation.

Technological Factors: The third cluster of variables is identified as technological factors. The research literature identifies a number of technology-related factors that potentially affect e-exporting adoption decisions. Technological factors include technology availability, cost, security, reliability and capabilities (Al-Dmour and Brandki, 2008). Al-Qirim (2004) examines relative advantage, cost and compatibility. Caldeira and Ward (2002) identify several technology variables including availability of external expertise and services, quality of software available in the market, vendor support, type of IS/IT solutions available to the firm, IS/IT objectives and assumptions and evaluation of IS/IT benefits. In Kanter's (2001) study of global digital trends, one of the most frequently identified barriers to adoption of EEIT was that technology and tools were inadequate, unavailable or unreliable (34\% of respondents) (Jensen, 2003). Raymond et al. (2001) examined the presence of and access to information networks. Some of the variation in factors and findings may be attributed to whether researchers focused exclusively on electronic commerce or used a somewhat broader definition of information technology. In addition, it is suggested that the successful use of Internet and e-commerce as a strategy for expansion into new markets is likely to be influenced by factors such as the technical infrastructure and the availability of IT literate personnel (Moodley, 2002). The related literature viewed cost as an important factor which influences innovation technology adoption (Talylor and Owusu, 2012, Lu et al., 2006; Mondragon et al., 2006). Talylor and Owusu (2012) indicate that high costs of development of Internet connectivity and website, high costs of computers and networking technologies for e-commerce, inadequate transportation and delivery network, inadequate telecommunications infrastructure and poor Internet connectivity were the main factors inhibiting FAAW's ability to adopt the technologies.

Various studies also address the impact of security risk on online business intention. For instance, the research of Ling et al. (2011) reveals that security risk is highly related to online trust, which in turn is positively related to business intention. Kim et al. (2008) found that the internet consumers' trust and perceived risk have strong impacts on their purchasing decisions. Chen and Barnes (2007) indicate that perceived security is one of the important antecedents to online initial trust, which has a positive impact on business intention. Mukherjee and Nath (2007) argue that privacy and security features of the e-commerce are the key antecedents of trust, which in turn positively influences relationship commitment. The sharing of information between exporters and foreign distributors can be done through e-commerce system. IT adoption in terms of software, hardware, and website development will facilitate the information sharing between exporters and foreign distributors. The advancement in IT means that communications among the two parties are more efficient now than in the past (Chong et al., 
2009). Security won't be an issue given that two parties get to know each other well and trust each other. Six technological factors are included in the current survey: Cost to setup and maintain (Cost); technology for selling products or services online (EC Technology); access to network services or infrastructure to support Web and Internet Technologies (Infrastructure); reliability of Web and Internet technologies (Reliability); security issues (Security); and availability or adequacy of existing technology (Technology Availability).

Environmental Factors: The second clusters of variables are identified as environmental factors such as competitive pressures, suppliers, vendors, partners and customers and government rules and regulations (Chong et al., 2009; Hsu et al., 2014).

Sociocultural Environments: it is an important factor for any organization trying to adopt new technology or system to its fullest potential. For example, the usefulness of a personal computer depends on the number of people who use computers and the wide range of available software. This is true for e-exporting too. Without the wide acceptance of applications or systems, current or potential customers may resist the adoption of e-exporting because of the lack of infrastructure, suitable platform, or compatible technological standards. The adoption of IT for foreign business processes and fulfilling revenue enhancement goals is likely to be influenced by cultural social norms. Some international business, particularly with high-context cultures, requires personal contacts and face-to- face meetings with the firm. This is because they usually need to have as much information as possible about the products of their interest and to have a higher level of trust on their business transactions. Exporting firms which adopted e-exporting approach would enable them to have much information as they wish about themselves in their corporate websites and to be local in many foreign markets through the adaptation of information to local users as well as to obtain instant reaction to its offers from distant markets (Bennett, 1997; Rosson, 2004). Based on the advantages described above, the use of e-exporting approach with a high-context cultures could be consideredas an alternative, or a new medium, to conventional international marketing based on personal contacts (Bennett, 1997) replacing foreign representation and enhancing export performance and profitability. Therefore, , it is suggested that Internet can help exporting companies to satisfy their customers need for personal contact in a very efficient way, resulting in an increase of their export revenues. Ghemawat (2001) explained the effect of distance on global business expansion through the "CAGE Distance Framework".

The framework is called "Cultural Distance" and it is created between two countries when there are four main attributes: a) different languages, b) different social norms, c) different religions, and d) different ethnicities. These attributes can have a huge impact on international trade as well as on the adoption of new technologies as commercial mediums, like the Internet. For example, all other things being equal, trade between countries that share a language will be three times greater than between countries without a common language. Some cultural attributes, like language, are easily perceived and understood while others are much more difficult. Social norms, the deeply rooted system of unspoken principles and common social habits that guide individuals in their everyday choices and interactions, are often nearly invisible, even to people who abide by them (Ghemawat, 2001). Cultural aspects, and more specifically language and social norms have a strong influence on the comprehensiveness and the efficacy of Internet-based exporting strategies (Azaria, 2010). Although English is the global language of business, exporters must be acutely aware that English fluency, even in developed nations, is not broad based. For customer-oriented companies who wish to overcome the problem of cultural distance, this means that they have to develop multi-language corporate websites to successfully reach their target markets and to communicate more effectively with their clients and suppliers (Samiee, 1998).

Government Rules and Regulations: In his paper, Moodley (2002) suggest that the government, trade unions, employers' associations and non-governmental organizations (NGOs) play important role in facilitating and enhancing exporting and access to global markets by internet for South African producers. Through direct interventions, governments have a considerable impact on the level of Internet penetration and usage. Chong et al. (2011) surveyed 114 Chinese SMEs participating in B2B e-marketplace and find that government plays an important role in making a great and reliable business e-condition. They thus recommend that governments should "facilitate and assist in the provision of information for the development and adaptation of B2B e-commerce at international level" (Chong et al., 2011). Government regulatory support includes the transparency of e-business regulations, the legal protection of firms when they do business over the Internet and legislation support for e-business. Previous studies have identified frequently government regulatory support as one of the key factor of e-commerce adoption (Hsu et al., 2006; Zhu et al., 2014; Zhu and Kraemer, 2005). Unlike government resource support, Government resource support is infrequently examined in the previous studies, and it could be an important element for developing economies (Van Huy et al., 2012). In addition, Osakwe et al. (2016) have suggest that government support in the shape of the provision of basic infrastructure and soft legislation may be considered to be a driver for firms in developing countries to adopt 
e-commerce. If not, government policies and regulations may bring uncertainty and risk (Abualrob and Kang, 2016). While a country's infrastructure is defined by its basic communication and transport capacity, many governmental have been the source of funding infrastructure projects. The influence of government policies and facilitates has been identified to have direct and indirect stimulation to the provision of information which produces faster technology adoption.

Competitors and Partners Pressures: Competitive pressure is a powerful predictor of innovation adoption for enterprises (Talylor and Owusu, 2012). Under the competing and rival pressure, they tend to be more responsive to and cautious about the actions of their competitors (Zhu and Kraemer, 2005). In oligopolies, the acceptance of technological innovations helps build or maintain barriers to entry and preserves cost advantage. Pressure from business partners and/or competitors has been found to be an important factor in electronic data interchange (EDI) adoption (Kosan and Kabuya, 2014). Export-import companies could develop voice package link with their customers and suppliers to reduce logistic cost and thereby be more competitive in the marketplace. Sometimes, companies develop Web pages simply because their competitors have Web pages. Thus, they are utilizing a me-too approach or, at best, they are imitating the leader's strategy. Consequently, these companies are failing to have solid and clear business objectives when using the Internet (Czuchry et al., 2002). The growth of the Internet initiatives of an organization depends not only on its own resources, but also on the readiness of its customers, suppliers and trading partners to engage in electronic interactions and transactions.

\section{Research Hypotheses}

Based upon theoretical background and literature review, the following null- hypotheses are developed and examined in this study:

Ho1: There is no any significant relationship between the determinants of the adoption of e-exporting factors (organizational, technological and environmental) and the extent of the implementation of e-exporting applications/activities; taken together or separately

Ho2: There is no any significant relationship between the determinants of the adoption of e-exporting factors and exporting performance

Ho3: There is no any significant relationship between the extent of the implementation of e-exporting applications and exporting performance

H04: The e-exporting applications are not significantly implemented among the manufacturing industrial companies in Jordan

H05: There is no significant difference among manufacturing industrial companies in terms of the e-exporting applications being implemented based on their size of business (number of employees)

H06: There is no significant difference among manufacturing industrial companies in terms of the e-exporting applications being implemented based on their business experience.

\section{Research Methodology}

To validate the study's conceptual model and examine the research hypotheses, self-administrated questionnaire was used to collect the required data. The target respondents were the business industrial companies in Jordan and the single key respondents approach was used. The key respondent was exporting or international marketing manager/director. The identification of the individual manufacturing companies in the country (Jordan) could be done by obtaining names of all of them, as well as their addresses, from several reliable sources in order to identify the type of industrial sector, and the range of the number of companies in each sector. The target population is only limited to manufacturing industrial exporting companies registered in Amman Chamber Industry (2018). Table (1) demonstrates the demographic characteristics of the study's population.

A total of 300 self-administrated questionnaires were distributed randomly to the respondents by e-mail and hand and the response rate was $55 \%$. In this survey, some variables are factual (for example, companies' demographic characteristics such as the type of industrial sector, experience and size), whereas others are attitudinal (determinants of the adoption of e-exporting). The dependent variables (i.e., the exporting business performance) and the independent variables (extent of the use e-exporting applications) were measured using a five-point Likert scale. The questionnaire's content (constructs and measures) were mainly selected from previous studies and were modified to the practice of Jordanian shareholding companies' context based on the results of a pilot study and feedback from five professional academic staff in this filed. 
Table 1. Demographic characteristics of the study's respondents

\begin{tabular}{|c|c|c|}
\hline Demographic Characteristics & Number & Percentages \\
\hline \multicolumn{3}{|l|}{ Type of Industrial sector } \\
\hline Engineering and steel construction & 30 & $18 \%$ \\
\hline Electronic computer and technology & 25 & $15 \%$ \\
\hline Clothing and carpets & 16 & $10 \%$ \\
\hline Food, tobacco and beverage & 23 & $14 \%$ \\
\hline Chemical and plastic & 34 & $11 \%$ \\
\hline Wood and furniture & 17 & 10 \\
\hline Plastic and leather & 18 & $11 \%$ \\
\hline \multicolumn{3}{|l|}{ Type of ownership structure } \\
\hline Sole Proprietorship & 12 & $7 \%$ \\
\hline Partnership & 22 & $13 \%$ \\
\hline Limited partnership & 28 & $17 \%$ \\
\hline Limited Liability Company & 47 & $29 \%$ \\
\hline Public listed Company & 53 & $33 \%$ \\
\hline \multicolumn{3}{|l|}{ Size: Number of employees } \\
\hline Less than 100 employees & 32 & $20 \%$ \\
\hline 100 to 174 employees & 57 & $35 \%$ \\
\hline 175 to 249 employees & 49 & $30 \%$ \\
\hline 250 and above employees & 25 & $15 \%$ \\
\hline \multicolumn{3}{|l|}{ Experience: Number of years in business } \\
\hline Less than 10 years & 44 & $27 \%$ \\
\hline 10 to 19 years & 67 & $41 \%$ \\
\hline 20 years and above & 52 & $32 \%$ \\
\hline Total & 163 & $100 \%$ \\
\hline
\end{tabular}

\section{Data Results and Discussion}

\subsection{Descriptive Statistics}

All the 42 items (30 items for the determinants of the adoption of e-exporting and 5 items for e-exporting applications, 7 items for exporting performance) were examined for their means, standard deviations, skewness, and kurtosis. The descriptive statistics presented below in Table 2 indicate a positive disposition towards the items. The standard deviation (SD) values ranged from 0.86924 to 1.25849 , these values indicate a narrow spread around the mean as well as the mean values of all items were greater than the midpoint (3) and ranged from 3.27 (TO12) to 3.93 (TO1). The values of skewness and kurtosis werefound normally distributedbecause ofthe mostof the values were inside the adequate ranges for normality (i.e. -1.0 to +1.0 ) for skewness, and less than 10 for kurtosis (Hair et al., 2010).

Table 2. Mean, standard deviation, and normality of scale items

\begin{tabular}{lllllc}
\hline \multicolumn{2}{l}{ Construct /items } & Mean & S.D & Skewness & Kurtosis \\
\hline \multicolumn{2}{l}{ E-exporting applications/activities } & & & & \\
\hline A1 & Online sales transactions( order and delivery) & 3.471 & 1.16052 & $-0.780-$ & $-0.283-$ \\
\hline A2 & Online customer service support and care & 3.352 & 1.17373 & $-0.807-$ & $-0.257-$ \\
\hline A3 & Online payment system (mode and terms) & 3.241 & 1.15313 & $-1.037-$ & 0.342 \\
\hline
\end{tabular}




\begin{tabular}{|c|c|c|c|c|c|}
\hline A4 & Online sales promotion and advertising & 2.821 & 1.13695 & $-0.571-$ & $-0.583-$ \\
\hline \multirow[t]{2}{*}{ A5 } & Online market research (collecting information) & 2.660 & 1.10677 & $-0.682-$ & $0-.291-$ \\
\hline & Average & 3.109 & & & \\
\hline \multicolumn{6}{|c|}{ Organizational Factors } \\
\hline & \multicolumn{5}{|l|}{ Top Management support } \\
\hline To1 & $\begin{array}{l}\text { Our top management is highly interested and } \\
\text { enthusiastic to make large investments into new IT } \\
\text { applications for exporting activities }\end{array}$ & 3.9325 & 1.17131 & $-1.058-$ & .332 \\
\hline To2 & $\begin{array}{l}\text { Our top management is highly committed to do } \\
\text { business in foreign market through the internet }\end{array}$ & 3.8896 & 1.22729 & $-.943-$ & $-.219-$ \\
\hline To3 & $\begin{array}{l}\text { Our top management is highly motivated in } \\
\text { promoting Internet use for exporting purposes }\end{array}$ & 3.7239 & 1.25849 & $-.687-$ & $-.623-$ \\
\hline To4 & $\begin{array}{l}\text { Our top management is highlycapable to take any } \\
\text { risks for doing business abroadthrough internet }\end{array}$ & 3.6135 & 1.08483 & $-.561-$ & $-.413-$ \\
\hline To5 & $\begin{array}{l}\text { Our top executives experienceswith computers and } \\
\text { the Internet is considered high }\end{array}$ & 3.5706 & 1.03619 & $-.747-$ & .108 \\
\hline \multirow[t]{2}{*}{ T06 } & $\begin{array}{l}\text { Our company's organizational culture is considered } \\
\text { innovative oriented }\end{array}$ & 3.5521 & 1.05499 & $-.618-$ & $-.091-$ \\
\hline & \multicolumn{5}{|c|}{ Organizational Commitment and Readiness } \\
\hline TO7 & $\begin{array}{l}\text { Our company has sufficient and adequate IT human } \\
\text { resources necessary to use internet and web } \\
\text { applications for exporting activities }\end{array}$ & 3.5460 & 1.06111 & $-.577-$ & $-.150-$ \\
\hline TO8 & $\begin{array}{l}\text { Our company has the necessity marketing } \\
\text { knowledge to use the Internetapplications for } \\
\text { exporting activities }\end{array}$ & 3.5215 & 1.09057 & $-.663-$ & $-.260-$ \\
\hline \multirow[t]{2}{*}{ TO9 } & $\begin{array}{l}\text { We have sufficient financial support touse internet } \\
\text { applications for exporting activities }\end{array}$ & 3.5031 & 1.08511 & $-.522-$ & $-.494-$ \\
\hline & \multicolumn{5}{|c|}{ Export Market orientation } \\
\hline TO10 & $\begin{array}{l}\text { Our company is consistently identifying and } \\
\text { responds to customer's needs in foreign markets }\end{array}$ & 3.3067 & 1.02639 & $-.473-$ & $-.375-$ \\
\hline TO11 & $\begin{array}{l}\text { Our company is consistently identifying and } \\
\text { responds tocompetitors' new marketing strategies in } \\
\text { foreign market }\end{array}$ & 3.3436 & 1.11875 & $-.525-$ & $-.367-$ \\
\hline TO12 & $\begin{array}{l}\text { Our company is consistently identifying and } \\
\text { responds to environmental changesin foreign } \\
\text { markets }\end{array}$ & 3.2761 & 1.15089 & $-.435-$ & -.628 \\
\hline
\end{tabular}

\section{Technological factor}

\begin{tabular}{|c|c|c|c|c|c|}
\hline IT1 & $\begin{array}{l}\text { The cost ofset up andmaintainsoperations for } \\
\text { on-line export operation is reasonable and } \\
\text { affordable }\end{array}$ & 3.5460 & 0.91761 & $-0.526-$ & -0.053 \\
\hline IT2 & $\begin{array}{l}\text { Availability and adequacy of existing technology is } \\
\text { considered supportive for the adoption of } \\
\text { e-exporting }\end{array}$ & 3.5767 & 0.91554 & $-0.474-$ & -0.219 \\
\hline IT3 & $\begin{array}{l}\text { The reliability of the currentuseof web and internet } \\
\text { support e-exporting }\end{array}$ & 3.5760 & 0.92893 & $-0.414-$ & -0.307 \\
\hline IT4 & $\begin{array}{l}\text { Access to network service support web and internet } \\
\text { technology }\end{array}$ & 3.4724 & 0.97697 & $-0.826-$ & 0.437 \\
\hline
\end{tabular}




\begin{tabular}{lllllll}
\hline IT5 & $\begin{array}{l}\text { The online security issues are considered important } \\
\text { for our e- exporting activities }\end{array}$ & 3.5890 & 0.88701 & $-0.542-$ & -0.018 \\
\hline IT6 & $\begin{array}{l}\text { Technology for selling products online is } \\
\text { considered important for the adopting of } \\
\text { e-exporting }\end{array}$ & & & & & \\
\hline
\end{tabular}

\begin{tabular}{|c|c|c|c|c|c|}
\hline \multicolumn{6}{|c|}{ EnvironmentalFactors } \\
\hline \multicolumn{6}{|c|}{ Sociocultural Factors } \\
\hline E1 & $\begin{array}{l}\text { Foreign market or customer base for e-commerce } \\
\text { influence our decision to use internet }\end{array}$ & 3.5583 & 1.14987 & $-.675-$ & $-.246-$ \\
\hline E2 & $\begin{array}{l}\text { Company's target foreign customers' levels of } \\
\text { Internet awareness influence our decision to use } \\
\text { internet for exporting activities }\end{array}$ & 3.5276 & 1.09043 & $-.505-$ & -.588 \\
\hline E3 & $\begin{array}{l}\text { Company's targetforeign customers' levels of access } \\
\text { to the Internet influence our decision to use internet } \\
\text { for exporting activities }\end{array}$ & 3.5092 & 1.18826 & $-.804-$ & $-.100-$ \\
\hline E4 & $\begin{array}{l}\text { The current size of on-line market place influence our } \\
\text { decision to use internet for exporting activities }\end{array}$ & 3.5031 & 1.03860 & $-.761-$ & .042 \\
\hline \multirow[t]{2}{*}{ E5 } & $\begin{array}{l}\text { The need of foreign customers for a personal contact } \\
\text { with the key persons of the exporting company } \\
\text { influence our decision to use internet for exporting } \\
\text { activities }\end{array}$ & 3.4847 & 1.04442 & $-.683-$ & $-.051-$ \\
\hline & Government Support & & & & \\
\hline \multirow[t]{2}{*}{ E6 } & $\begin{array}{l}\text { Local government rules and regulationsis considered } \\
\text { supportive factor to use internet }\end{array}$ & 3.4724 & 1.14565 & $-.580-$ & -.409 \\
\hline & Competitive and Partner pressures & & & & \\
\hline E7 & $\begin{array}{l}\text { Competitive pressure within our industry force us to } \\
\text { use e-exporting applications }\end{array}$ & 3.4233 & 1.10496 & $-.734-$ & $-.213-$ \\
\hline E8 & $\begin{array}{l}\text { Level of Internet usage by competitors in foreign } \\
\text { markets motivate usto use internet for exporting } \\
\text { activities }\end{array}$ & 3.4172 & 1.11009 & $-.638-$ & $-.341-$ \\
\hline E9 & $\begin{array}{l}\text { Level of firm's pressures derived from } \\
\text { foreign suppliers is important factor for the } \\
\text { adoptionof e-exporting }\end{array}$ & 3.3926 & 1.16235 & $-.643-$ & $-.391-$ \\
\hline E10 & $\begin{array}{l}\text { The firm'spartnerpressure in foreign market } \\
\text { wouldinfluence our decision positivelyto use } \\
\text { e-exporting }\end{array}$ & 3.3865 & 1.17234 & $-.561-$ & $-.441-$ \\
\hline E11 & $\begin{array}{l}\text { High portion of our company's sales depends on } \\
\text { foreign agents or representatives for distribution } \\
\text { influence our decision to use internet for exporting } \\
\text { activities }\end{array}$ & 3.3742 & 1.10602 & $-.619-$ & -.334 \\
\hline E12 & $\begin{array}{l}\text { The availability of local vendor supportin terms of } \\
\text { quality of internet and web design encourage us to } \\
\text { use e-exporting applications }\end{array}$ & 3.4233 & 1.10496 & $-.734-$ & $-.213-$ \\
\hline \multicolumn{6}{|c|}{ Exporting performance } \\
\hline $\mathrm{P} 1$ & $\begin{array}{l}\text { The Internet has significantly improved our export } \\
\text { profits }\end{array}$ & 3.4969 & 1.11319 & $-.617-$ & $-.251-$ \\
\hline $\mathrm{P} 2$ & $\begin{array}{l}\text { The Internet has significantly improved our export } \\
\text { sales volume }\end{array}$ & 3.4908 & 1.09639 & $-.645-$ & -.370 \\
\hline
\end{tabular}




\begin{tabular}{lllllll}
\hline P3 & $\begin{array}{l}\text { The Internet has significantly improved our export } \\
\text { market share }\end{array}$ & 3.5215 & 1.16713 & $-.666-$ & $-.425-$ \\
\hline P4 & $\begin{array}{l}\text { The Internet has significantly improved our overall } \\
\text { performance }\end{array}$ & 3.5153 & 1.11309 & $-.664-$ & $-.307-$ \\
\hline P5 & $\begin{array}{l}\text { The Internet has significantly improved ouroverall } \\
\text { image and reputation }\end{array}$ & 3.4417 & 1.18685 & $-.577-$ & $-.553-$ \\
\hline P6 & $\begin{array}{l}\text { The Internet has significantly improved our } \\
\text { customer's satisfaction }\end{array}$ & & & & & \\
\hline P7 & $\begin{array}{l}\text { The Internet has significantly improved our } \\
\text { shareholders' satisfaction }\end{array}$ & 3.5031 & 1.12970 & $-.697-$ & $-.338-$ \\
\hline
\end{tabular}

\subsection{The Extent of the Implementation of E-Exporting Marketing Activities}

The measure of extent of e-exporting marketing activities (applications) implementation were selected and identified from the previous studies and they are including: (1) sales transactions (order and delivery), (2) customer service support and care, (3) payment system, (4) sales promotion and advertising and (5) marketing research.The mean values, standard deviation and T-test are employed here to determine whether these activities are implemented and by exporting industrial companies in Jordan (Table 3). Findings shown in Table 8.1 indicate that the extent of these e-exporting activities being practiced is considered to be reasonable/moderate (i.e. $62 \%$ or $3.1 \%$ ). since their mean are more than the mean of the scale, which is 3 (mean of the scale $=\Sigma$ Degrees of the scale $5=1+2+3+4+5 / 5=3$ ). This implies that there are some variations among exporting industrial companies in terms of their level of implementations of e-exporting marketing activities as presented in Table 3 and it might be attributed to their level of involvement in exporting. The mean values have shown that the "online sales transaction" as an e-exporting activity is the highly practiced one (69\%), and the marketing research (collecting information) is the lowest practiced one (0.53).

Table 3. The extent of the implementation of e-exporting applications

\begin{tabular}{|c|c|c|c|c|c|}
\hline & Exporting Applications & Mean & Percentage & $\begin{array}{r}\text { Standard } \\
\text { deviation }\end{array}$ & Sig. (2-tailed) \\
\hline A1 & $\begin{array}{l}\text { Online sales transactions (order and } \\
\text { delivery) }\end{array}$ & 3.471 & 0.694 & 1.16052 & 0.000 \\
\hline A2 & $\begin{array}{l}\text { Online customer service support and } \\
\text { care( (after sales) }\end{array}$ & 3.352 & 0674 & 1.17373 & 0.000 \\
\hline A3 & $\begin{array}{l}\text { Online payment system (mode and } \\
\text { terms) }\end{array}$ & 3.241 & 0.648 & 1.15313 & 0.000 \\
\hline A4 & Online sales promotion and advertising & 2.821 & 0.564 & 1.13695 & 0.000 \\
\hline \multirow[t]{2}{*}{ A5 } & $\begin{array}{l}\text { Online market research (collecting } \\
\text { information) }\end{array}$ & 2.660 & 0532 & 1.10677 & 0000 \\
\hline & Average practice & 3.109 & 0.622 & 1.03550 & 0.000 \\
\hline
\end{tabular}

\section{Data Analysis Techniques}

\subsection{Factor Analysis Results}

The main purpose behind the use of factor analysis techniques is to reduce the large number of variables that underlie each major construct into orthogonal indices for further analysis by the regression analysis. Furthermore, by employing the principle component analysis techniques, it may be possible to explore the patterns of factors that underlie study's conceptual framework. It was considered an appropriate method to overcome the potential problems of multicollinearity among the variables that pertain to each construct. A pre-analysis was conducted to examine the appropriateness of the data for factor analysis, and then the results of the factor analysis were examined using multiple criteria, including eigenvalues, interpretability and internal consistency, as recommended by Hair et al. (2010). Therefore, the items determined to have eigenvalues greater than one and 
factor loadings less than .40 had little or no relationship with one another; hence, they were discarded (Hair et al., 2010). The results of the principle components analysis indicate that three major factors can be extracted from the determinants of the adoption of e-exporting. The preliminary examination of the correlation matrix for this construct revealed acceptable inter-correlations well above 0.30. A further examination of the data matrix indicated the Bartlett's test was significant at $(\mathrm{p}>0.000)$, with an acceptable KMO measure of adequacy 0.932 , indicating that the factor analysis could advance as it had a high amount of variance around $93 \%$ in the data, which can be explained by this construct as presented in Table 4 .

Table 4. KMO and Bartlett's test

\begin{tabular}{|c|c|c|}
\hline \multicolumn{3}{|c|}{ KMO and Bartlett's Test } \\
\hline Kaiser-Mey & r-Olkin Measure of Sampling Adequacy. & 0.962 \\
\hline \multirow{3}{*}{$\begin{array}{l}\text { Bartlett's } \\
\text { Sphericity }\end{array}$} & Test of Approx. Chi-Square & 7062.951 \\
\hline & Df & 435 \\
\hline & Sig. & 0.000 \\
\hline
\end{tabular}

The results of the principal component analysis in Table 5 indicate that three significant factors can be extracted from this construct. This construct composed of 30 items (variables). The first factor, which accounts for $(31.85 \%)$ of the variance with loadings ranging from 0.697 to 0.776 , can be identified as an "Environmental" factor. The second factor, which explains $26.4182 \%$ of variance with loadings range from 0.561 to 0.858 , can be labelled as "Organizational" factor. The third factor which accounts for 22.091 can be identified as "Technological" factor. The combinations of these factors accounts for 80.125 of the total variance in the questionnaire data as can be shown in Table 5. In summary, based on the preliminary analysis, the evaluation of the data by factor analysis and reliability estimates indicated that all scale items were appropriate and valid for further statistical analysis. As this measure was adapted from an existing scale, the computed Cronbach's Alpha level of 0.941 indicated the items were highly reliability. These results support the proposition that the compound measurement tool used in this study is a valid approach to assess factors of the adoption of e-exporting.

Table 5. Total variance explained

\begin{tabular}{cccc}
\hline Component/ Factor & \multicolumn{3}{c}{ Rotation Sums of Squared Loadings } \\
\cline { 2 - 4 } & Eigenvalue & \% of Variance & Cumulative \% \\
1 & 20.731 & 31.851 & 31.851 \\
2 & 1.857 & 26.182 & 58.034 \\
3 & 1.450 & 22.091 & 80.125 \\
\hline
\end{tabular}

Table 6. The main factors underlying determinants of e-exporting

\begin{tabular}{llcc}
\hline Code & Items (variables) & Loadings & Communality \\
\hline Factor (1) Environmental & & 0.829 \\
\hline E3 & $\begin{array}{l}\text { Company's targetforeign customers' levels of access to the } \\
\text { Internet influence our decision to use internet for exporting } \\
\text { activities }\end{array}$ & 0.776 & 0.776 \\
\hline E2 & $\begin{array}{l}\text { Company's target foreign customers levels of Internet } \\
\text { awareness influence our decision to use internet for } \\
\text { exporting activities }\end{array}$ & 0.768 & 0.776 \\
\hline E9 & $\begin{array}{l}\text { Level of firm's pressures derived from foreign suppliers is } \\
\text { important factor for the adoptionof e-exporting }\end{array}$ & 0.757 & 0.780 \\
\hline E1 & $\begin{array}{l}\text { Foreign market or customer base for e-commerce influence } \\
\text { our decision to use internet for exporting activities }\end{array}$ & 0.753 & \\
\hline
\end{tabular}




\begin{tabular}{|c|c|c|c|}
\hline E8 & $\begin{array}{l}\text { Level of Internet usage by competitors in foreign markets } \\
\text { motivate usto use internet for exporting activities }\end{array}$ & 0.748 & 0.792 \\
\hline E6 & $\begin{array}{l}\text { Local government rules and regulationsis considered } \\
\text { supportive factor to use internet for exporting purposes }\end{array}$ & 0.743 & 0.778 \\
\hline E5 & $\begin{array}{l}\text { The need of foreign customers for a personal contact with } \\
\text { the key persons of the exporting company influence our } \\
\text { decision to use internet for exporting activities }\end{array}$ & 0.738 & 0.787 \\
\hline E10 & $\begin{array}{l}\text { The firm'spartnerpressure in foreign market } \\
\text { wouldinfluence our decision positivelyto use e-exporting }\end{array}$ & 0.737 & 0.809 \\
\hline E4 & $\begin{array}{l}\text { The current size of on-line market place influence our } \\
\text { decision to use internet for exporting activities }\end{array}$ & 0.733 & 0.779 \\
\hline E7 & $\begin{array}{l}\text { Competitive pressure within our industry force us to use } \\
\text { e-exporting applications }\end{array}$ & 0.732 & 0.822 \\
\hline E12 & $\begin{array}{l}\text { The availability of local vendor supportin terms of quality } \\
\text { of internet and web design encourage us to use e-exporting } \\
\text { applications }\end{array}$ & 0.727 & 0.805 \\
\hline E11 & $\begin{array}{l}\text { High portion of our company's sales depends on foreign } \\
\text { agents orrepresentatives for distribution influence our } \\
\text { decision to use internet for exporting activities }\end{array}$ & 0.697 & 0.756 \\
\hline \multicolumn{4}{|c|}{ Factor (2) Organizational } \\
\hline To11 & $\begin{array}{l}\text { Our company is consistently identifying and responds } \\
\text { tocompetitors' new marketing strategies in foreign market }\end{array}$ & 0.858 & 0.836 \\
\hline To12 & $\begin{array}{l}\text { Our company is consistently identifying and responds to } \\
\text { environmental changesin foreign markets }\end{array}$ & 0.839 & 0.823 \\
\hline To10 & $\begin{array}{l}\text { Our company is consistently identifying and responds to } \\
\text { customer's needs in foreign markets }\end{array}$ & 0.802 & 0.809 \\
\hline To9 & $\begin{array}{l}\text { We have sufficient financial support touse internet } \\
\text { applications for exporting activities }\end{array}$ & 0.715 & 0.750 \\
\hline To4 & $\begin{array}{l}\text { Our top management is highlycapable to take any risks for } \\
\text { doing business abroad through internet }\end{array}$ & 0.703 & 0.684 \\
\hline To7 & $\begin{array}{l}\text { Our company has sufficient and adequate IT human } \\
\text { resources necessary to use internet and web applications } \\
\text { for exporting activities }\end{array}$ & 0.679 & 0.700 \\
\hline To8 & $\begin{array}{l}\text { Our company has the necessity marketing knowledge to } \\
\text { use the Internetapplications for exporting activities }\end{array}$ & 0.671 & 0.745 \\
\hline To6 & $\begin{array}{l}\text { Our company's organizational culture is considered } \\
\text { innovative oriented }\end{array}$ & 0.640 & 0.735 \\
\hline To3 & $\begin{array}{l}\text { Our top management is highly motivated in promoting } \\
\text { Internet use for exporting purposes }\end{array}$ & 0.603 & 0.744 \\
\hline To1 & $\begin{array}{l}\text { Our top management is highly interested and enthusiastic } \\
\text { to make large investments into new IT applications for } \\
\text { exporting activities }\end{array}$ & 0.581 & 0.703 \\
\hline To2 & $\begin{array}{l}\text { Our top management is highly committed to do business in } \\
\text { foreign market through the internet }\end{array}$ & 0.574 & 0.745 \\
\hline To5 & $\begin{array}{l}\text { Our top executives experienceswith computers and the } \\
\text { Internet is considered high }\end{array}$ & 0.561 & 0.738 \\
\hline
\end{tabular}

Factor (3)Technological 


\begin{tabular}{llccc}
\hline IT4 & $\begin{array}{l}\text { Access to network service support web and internet } \\
\text { technology }\end{array}$ & 0.861 & 0.972 \\
\hline IT2 & $\begin{array}{l}\text { Availability and adequacy of existing technology is } \\
\text { considered supportive for the adoption of e-exporting }\end{array}$ & 0.858 & 0.966 \\
\hline IT1 & $\begin{array}{l}\text { The cost ofset up andmaintainsoperations for on-line export } \\
\text { operation is reasonable and affordable }\end{array}$ & 0.855 & 0.954 \\
\hline IT5 & $\begin{array}{l}\text { The online security issues are considered important for our } \\
\text { e- exporting activities }\end{array}$ & 0.848 & 0.933 \\
\hline IT3 & $\begin{array}{l}\text { The reliability of the currentuseof web and internet support } \\
\text { e-exporting }\end{array}$ & 0.865 & 0.941 \\
\hline IT6 & $\begin{array}{l}\text { Technology for selling products online is considered } \\
\text { important for the adopting of e-exporting }\end{array}$ & 0.617 & 0.772 \\
\hline
\end{tabular}

\subsection{Multicollinearity Diagnostics}

Table (7) presents the multicollinearity diagnostics of the study independent factors. The values of variance inflation factor (VIF) and the values of tolerance are determined to notice the multicollinearity. And if the value of tolerance is less than 0.1 and the value (VIF) of are greater than 10, it displays that the multicollinearity is problematic. The results in table (20) indicate that all values of (VIF) are less than 10 and all values tolerance are more than (0.1), Which indicates that there is no problem with multicollinearity among the study independent variables. So, the study construction is valid and that we can test the hypothesis based on these outcomes.

Table 7. The multicollinearity diagnostics

\begin{tabular}{lcc}
\hline \multicolumn{1}{c}{ Factors } & VIF & Tolerance \\
\hline Organizational Factors & 1.00 & 1.00 \\
Technological Factors & 1.00 & 1.00 \\
Environmental Factors & 1.00 & 1.00 \\
\hline
\end{tabular}

\subsection{Testing Hypotheses}

Multiple regression analysis technique was used to examine the following hypotheses (HO1, Ho2 and Ho3):

Ho1: There is no any significant relationship between the determinants of the adoption of e-exporting factors (organizational, technological and environmental) and the extent of the implementation of e-exporting applications/activities; taken together or separately

Table (8) summarizes the results of multiple regression analysis, with the F-ratio test for the above hypothesis. The results of the multiple correlation coefficient $(\mathrm{R}=0.87)$ value indicate that there is significant and strongrelationship between the determinants of the adoptionof e-exporting factors (organizational, technological and environmental) and the extent of implementation of e-exporting applications/activities; either taken separately or together at 0.000 level of significance. The value of the coefficient of determination (R Square) also indicate that 0.76 of variance in extent of the implementation of e-exporting could be explained by these factors together.

According to the stepwise multiple regression method, the factors which highly correlated with the dependent variable (i.e., the level of implementation of e-exporting applications) is expected to enter into the regression equation. The $\mathrm{F}$ value at 0.00 level of significance is used to determine the "goodness of fit" for the regression equation. Thefindings of the stepwise multiple regression indicate that all the three major factorsincluded inthe equation and these factors in terms of their relative importance (beta coefficient), the organizational factors, environmental and technological factors respectively.Thus, it can be concluded that the organizational, environmental and technological factors should be all considered respectively in the case of evaluation of the level of the implementation of e-exporting applications by the exporting industrial companies in Jordan. This is result is in consistent with proposed technology accepted model. 
Table 8. A summary result of the multiple regressions of Ho1

\begin{tabular}{|c|c|c|c|c|c|c|c|c|}
\hline \multirow[t]{3}{*}{ Variables } & \multicolumn{3}{|c|}{ Model summary } & \multicolumn{2}{|c|}{ ANOVA } & \multicolumn{2}{|c|}{ Coefficients(a) } & \multirow{3}{*}{ Beta } \\
\hline & $\mathrm{R}$ & R Square & $\begin{array}{l}\text { Adjusted R } \\
\text { Square }\end{array}$ & F-value & Sig & \multirow[t]{2}{*}{$\mathrm{T}$} & \multirow{2}{*}{$\begin{array}{l}\text { Sig.(P- } \\
\text { value) }\end{array}$} & \\
\hline & $0.872^{\mathrm{a}}$ & 0.760 & 0.755 & 167.65 & 0.000 & & & \\
\hline Constant & & & & & & 92.32 & 0.000 & 3.704 \\
\hline organizational & & & & & & 14.71 & 0.000 & 0.595 \\
\hline Environmental & & & & & & 13.24 & 0.000 & 0.532 \\
\hline Technological & & & & & & 10.44 & 0.000 & 0.421 \\
\hline
\end{tabular}

Ho2: There is no any significant relationship between the determinants of the adoption of e-exporting factors and exporting performance

Table (9) summarizes the results of multiple regression analysis for the second hypothesis. The results show that there is a strong and significant correlation between the determinants of e-exporting factors (organizational, environmental and technological) and exporting performance either taken together or separately at the level of 0.000 . The value of $\mathrm{R}$ square express that $(83 \%)$ of the variance in exporting performance was explained by these factor when they were taken together. The stepwise multiple regression analysis results indicate that all the extracted determinants factors of the implementation of e-exporting applications (organizational, environmental and technological ) included in the equation and the beta Coefficients forall of these factors indicate that the external environmentalfactors are the most important factors influencing the export performance. Therefore, it can be concluded that the environmental, organizational and technological factors respectively play important role in the predication of exporting performance.

Table 9. A summary result of the multiple regressions of $\mathrm{Ho} 2$

\begin{tabular}{|c|c|c|c|c|c|c|c|c|}
\hline \multirow[t]{3}{*}{ Variables } & \multicolumn{3}{|c|}{ Model summary } & \multicolumn{2}{|c|}{ ANOVA } & \multicolumn{2}{|c|}{ Coefficients(a) } & \multirow{3}{*}{ Beta } \\
\hline & $\mathrm{R}$ & R Square & $\begin{array}{l}\text { Adjusted R } \\
\text { Square }\end{array}$ & F-value & Sig & \multirow[t]{2}{*}{$\mathrm{T}$} & \multirow{2}{*}{$\begin{array}{l}\text { Sig.(P- } \\
\text { value) }\end{array}$} & \\
\hline & $0.911^{\mathrm{a}}$ & 0.830 & 0.827 & 259.29 & 0.000 & & & \\
\hline Constant & & & & & & 102.7 & 0.000 & 3.495 \\
\hline Environmental & & & & & & 20.20 & 0.000 & 0.689 \\
\hline Organizational & & & & & & 15.92 & 0.000 & 0.543 \\
\hline Technological & & & & & & 10.78 & 0.000 & 0.368 \\
\hline
\end{tabular}

Ho3:There is no any significant relationship between the extent of the implementation of e-exporting applications and exporting performance

A summary result of multiple regression analysis for above hypothesis in Table (10) indicate that there is a strong and significant relationship between the extent of the implementation of e-exporting applications (i.e. marketing activities) and exporting performance when they were taken together at the level of significance 0.000 , while only one application was found insignificance when it was taken separately (i.e., advertising and promotion). The value of R-square indicate that about $73 \%$ of variance in exporting performance could be explained these e-exporting applications together. Therefore, it might be concluded that the extent of the implementation of e-exporting applications by Jordanian industrial exporting companies could make positive /better variations in their exporting performance. 
Table 10. A summary result of the multiple regressions of Ho3

\begin{tabular}{|c|c|c|c|c|c|c|c|c|}
\hline \multirow[t]{3}{*}{ Variables } & \multicolumn{3}{|c|}{ Model summary } & \multicolumn{2}{|c|}{ ANOVA } & \multicolumn{2}{|c|}{ Coefficients(a) } & \multirow{3}{*}{ Beta } \\
\hline & $\mathrm{R}$ & R Square & $\begin{array}{l}\text { Adjusted R } \\
\text { Square }\end{array}$ & F-value & Sig & \multirow[t]{2}{*}{$\mathrm{T}$} & \multirow{2}{*}{$\begin{array}{l}\text { Sig. }(\mathrm{P}- \\
\text { value })\end{array}$} & \\
\hline & $0.855^{\mathrm{a}}$ & 0.731 & 0.723 & 85.528 & 0.000 & & & \\
\hline Constant & & & & & & 1.834 & 0.068 & 0.296 \\
\hline A1 & \multicolumn{5}{|c|}{ Online sales transactions( order and delivery) ) } & 3.509 & 0.001 & 0.227 \\
\hline A2 & \multicolumn{5}{|c|}{$\begin{array}{l}\text { Online customer service support and care( (after } \\
\text { sales) }\end{array}$} & 2.128 & 0.035 & 0.157 \\
\hline A3 & \multicolumn{5}{|c|}{ Online payment system (mode and terms) } & 2.058 & 0.041 & 0.170 \\
\hline A4 & \multicolumn{5}{|c|}{ Online sales promotion and advertising } & 0.726 & 0.469 & 0.053 \\
\hline A5 & \multicolumn{5}{|c|}{ Online market research (collecting information) } & 3.692 & 0.000 & 0.258 \\
\hline
\end{tabular}

H04: The e-exporting applications are not significantly implemented among the manufacturing industrial companies in Jordan.

One-sample t-test is employed to examine the fourth hypothesis (Ho4) in the study. The result in the Table 11 shows that the e-exporting applications are significantly being implemented by manufacturing industrial exporting companies; either taken separately or together.

H05: There is no significant difference among manufacturing industrial companies in terms of the e-exporting applications being implemented based on their size of business (number of employees).

H06: There is no significant difference among manufacturing industrial companies in terms of the e-exporting applications being implemented based on their business experience (number of years on business).

The ANOVA analysis technique is used to examine the above hypotheses (Ho6, and Ho7. It is used to assess the differences among manufacturing industrial exporting companies in terms of the extent of implementation of e-exporting application/activitiesbased on their business'ssize (number of employees)and business experience (number of years in business). Tables 11 and 12 summarize the results of ANOVA analysis for the two above hypotheses. The results indicate that the level of implementations of e-exporting applications are significantly varied among manufacturing industrial exporting companies due to her size and experience in business.

Table 11. The level of implementation of e-exporting applications based on the size of business

\begin{tabular}{llccccc}
\hline Code & & Sum of Squares & Df & Mean Square & F & Sig. \\
\hline A1 & Between Groups & 111.754 & 4 & 27.938 & 39.61 & 0.000 \\
& Within Groups & 111.424 & 158 & 0.705 & & \\
& Total & 223.178 & 162 & & & \\
A2 & Between Groups & 111.726 & 4 & 27.932 & 45.17 & 0.000 \\
& Within Groups & 97.685 & 158 & 0.618 & & \\
& Total & 209.411 & 162 & & & \\
A3 & Between Groups & 118.007 & 4 & 29.502 & 47.85 & 0.000 \\
& Within Groups & 97.404 & 158 & 0.616 & & \\
& Total & 215.411 & 162 & & & \\
A4 & Between Groups & 115.308 & 4 & 28.827 & 44.27 & 0.000 \\
& Within Groups & 102.876 & 158 & 0.651 & & \\
& Total & 218.184 & 162 & & & \\
A5 & Between Groups & 95.338 & 4 & 23.835 & 36.52 & 0.000 \\
\hline
\end{tabular}




\begin{tabular}{llccccc}
\hline \multirow{4}{*}{ Total } & Within Groups & 103.103 & 158 & 0.653 & & \\
& Total & 198.442 & 162 & & & \\
& Between Groups & 108.476 & 4 & 27.119 & 65.68 & 0.000 \\
& Within Groups & 65.231 & 158 & 0.413 & & \\
& Total & 173.707 & 162 & & & \\
\hline
\end{tabular}

Table 12. Level of implementation of e-exporting applications based on the business experience

\begin{tabular}{llccccc}
\hline Code & & Sum of Squares & Df & Mean Square & F & Sig. \\
\hline A1 & Between Groups & 51.913 & 3 & 10.383 & 9.518 & 0.000 \\
& Within Groups & 171.265 & 159 & 1.091 & & \\
& Total & 223.178 & 162 & & & \\
A2 & Between Groups & 50.648 & 3 & 10.130 & 10.017 & 0.000 \\
& Within Groups & 158.763 & 159 & 1.011 & & \\
& Total & 209.411 & 162 & & & \\
A3 & Between Groups & 46.640 & 3 & 9.328 & 8.677 & 0.000 \\
& Within Groups & 168.771 & 159 & 1.075 & & \\
& Total & 215.411 & 162 & & & \\
A4 & Between Groups & 74.332 & 3 & 14.866 & 16.225 & 0.000 \\
& Within Groups & 143.852 & 159 & 0.916 & & \\
& Total & 218.184 & 162 & & & \\
A5 & Between Groups & 59.671 & 3 & 11.934 & 13.502 & 0.000 \\
& Within Groups & 138.771 & 159 & 0.884 & & \\
& Total & 198.442 & 162 & & & \\
Total & Between Groups & 54.739 & 3 & 10.948 & 14.448 & 0.000 \\
& Within Groups & 118.968 & 159 & 0.758 & & \\
& Total & 173.707 & 162 & & & \\
\hline
\end{tabular}

\section{Discussion and Implications}

One of the main objectives of this study is to examine to which extent the manufacturing industrial exporting companies in Jordan implemented e-exporting marketing activities (applications). The results indicate that the extent of e-exporting applications being practiced is considered to be satisfactory (i.e. $62 \%$ or $3.1 / 5$ ). It implies that there are some variations among these companies in terms of their level of implementations of e-exporting marketing activities (applications) as presented in Table (3). This might be due to their level of involvement in exporting activities. Mean values have shown that the online sales transactions (order and delivery) and online customer service support and care (after sales) were the highly implemented e-exporting applications respectively (69\% and 67\%). The second objective is to compare differences among exporting companies in terms e-exporting marketing applications being implemented based on their type of business, size and experience. Interestingly, the study found significant differences among exporting companies in extent of e-exporting marketing applications being implemented due to their size and experience in exporting. This result is supporting by many previous study Bianchi and Mathews (2012) and Zhang and Okoroafor (2013).

The third objective is to examine and validate the study's conceptual framework. The results of FA indicated that 30 variables which were expected to influence the level of the implementation of e-exporting activities could be grouped into three major factors: organizational, environmental and technological. This result is in consistent with the Technology, organizational, and environmental (TOE) framework developed by Tornatzky and Fleischer (1990) and the previous studies that have used this framework in the context of IT adoption (e.g. Ramdani and Kawalek, 2007; Scupola, 2003; Al-Dmour, et al., 2013). These major factors were found significantly related to 
the level of implementation of e-exporting activates as well as the exporting performance. R. adjusted square results indicated that these three major factors; taken together could explain $76 \%$ and $83 \%$ of the variation on the level of e-exporting applications being implemented and the exporting performance respectively.

Furthermore, in terms of their importance, while the results have shown that organizational factor is most important one influencing the extent of the level of implementation of e-exporting applications, the environmental factor is the most important one influencing the exporting performance. This result indicated that internal factors (organizational) are more important than external (environmental) factors to the level of the implementation of e-exporting activities. Therefore, companies needed to reevaluate their internal organizational (top management support, competences, resources) if they decided to expanded into foreign markets using e-exporting approach. However, business organizations which interested to improve their exporting performance should develop appropriate marketing strategies in order to deal with external environmental factors (competition pressure, foreign governmental regulations, supplies and customers) in foreign market. The fourth objective is to examine the relationship between the extent of the implementation of e-exporting applications and exporting performance. The result indicated that there was a significant relationship between the extent of the implementation of e-exporting applications and export performance.

This study has contributed to the extent e-exporting literature by providing the following. First, the study has investigated the unexplored differences between the factors determine the extent of the implementation of e-exporting andfactors determine the export performance using Technology, organizational, and environmental (TOE) framework developed by Tornatzky and Fleischer (1990). Second, this study considered, to the best of the author's knowledge, is the first to testing the impact of extent of the implementation of e-exporting being practiced upon the export performance, within the context of Jordanian industrial companies. Previous research on this area investigated heavily conducted in developing countries.

The present study has important implications for studies aimed to e-exporting in developing countries. However, explanations of several findings above indicate the importance of contextual factors (i.e., demographic characteristics) within organizations. This study provides some insights into the implementation of e-exporting activities by Jordanian exporting companies, which should help practitioners to acquire a better understanding of the current e-exporting status and implementation. However, several limitations should be considered when evaluating and generalizing the study's conclusions. The study was conducted in one country, Jordan. Although Jordan is a valid indicator of prevalent factors in the wider MENA region and developing countries, the lack of external validity of this research means that any generalizations of the research findings should be taken with caution. Future research can be orientated in other national and cultural settings and compared with the results of this study.

\section{References}

Abualrob, A., \& Kang, Y. (2016). The barriers that hinder the adoption of e-commerce by small businesses: Unique hindrance in Palestine. Information Development, 32(5), 1528-1544.

Afuah, A. (2003). Redefining firm boundaries in the face of the internet: Are firms really shrinking? Academy of Management Review, 28(1), 34-53.

Ajzen, I. (1991). The theory of planned behavior. Organizational Behavior and Human Decision Processes, 50(2), 179-211.

Al-Dmour, A, Al-Dmour, R., \& Masa'deh, R. (2016). Interrelated factors influencing the adoption decision of AIS applications by SMEs in Jordan. International Business Research, 9(10), 47-62.

Al-Dmour, H., \& Brandki, A. (2008). Internet export marketing by Jordanian and Italian small-medium sized enterprises: A comparative study. DIRASAT (Adm. Sciences), 35(2), 234-259.

Al-Dmour, R, Love, S., \& Al-Zu'bi, Z. (2013). Factors influencing the adoption of HRIS applications: A literature review. International Journal of Management \& Business Studies, 3(4), 9-21.

Al-Dmour, R, Obeidat, B., \& Almajali, D. (2015). The practice of HRIS applications in business organizations in Jordan: An empirical study. 4th Scientific \& Research Conference on New Trends in Business, Management and Social Sciences (COES\&RJ-TK15/1).

Al-Dmour, R., Al Haj Dawood, E., Al-Dmour, H., \& Masa'deh, R. (2019). The effect of customer lifestyle patterns on the use of mobile banking applications in Jordan. Int. J. Electronic Marketing and Retailing, Forthcoming.

Aldmour, R., Masa'deh, R., \& Obeidat, B. (2017). Factors influencing the adoption and implementation of HRIS 
applications: Are they similar. International Journal of Business Innovation and Research, 14(2), 139-167.

Al-Qirim, N. A. (2007). E-commerce adoption in small businesses: Cases from New Zealand. Journal of Information Technology Case \& Application Research, 9(2), 28-57.

Armario, J. M., Ruiz, D. M., \& Armario, E. M. (2008). Market orientation and internationalization in small and medium-sized enterprises. Journal of Small Business Management, 46, 485-511.

Arnott, D., \& Bridgewater, S. (2002). Internet, interaction and implications for marketing. Marketing Intelligence \& Planning, 20(2), 86-89.

Avlonitis, G., \& Karayanni, D. (2000). The impact of internet use on business to business marketing: Examples from American and European companies. Indust Marketing Manag, 29, 441-459.

Ayan, T. Y., \& Percin, S. (2005). A structural analysis of the determinants of export performance: Evidence from Turkey. Innovative Marketing, 1(2), 106-120.

Azaria, C. (2010). Export commerce and export marketing with the use of internet by Greek SMEs, Doctoral Dissertation, University of Macedonia, Greece.

Bauer, H. H., Grether, M., \& Leach, M. (2002). Building customer relations over the internet. Industrial Marketing Management, 31, 155-163.

Bennett R. (1998). Using the world wide web for international marketing: Internet use and perceptions of export barriers among German and British businesses. J Market Comm, 4, 27-43.

Bennett, R. (1997). Export marketing and the internet. International Marketing Review, 14(5), 324-344.

Berry, M., \& Brock, J. (2004). Marketspace and the internationalisation process of the small firm. Journal of International Entrepreneurship, 2, 187-216.

Bianchi, C. (2011). The growth and international expansion of an emerging market retailer in Latin America. Journal of Global Marketing, 24(4), 357.

Bianchi, C., \& Mathews, S. (2013). The role of the internet on export market growth: An empirical study in Latin America. In Strategic Management in Latin America, Mexico City, Mexico.

Biswas, A., \& Krishnan, R. (2004). The internet's impact on marketing: Introduction to the JBR special issue on "Marketing on the web-behavioral, strategy and practices and public policy". Journal of Business Research, 57(7), 681-684.

Caldeira, M. M., \& Ward, J. M. (2002). Understanding the successful adoption and use of IS/IT in SMEs: An explanation from Portuguese manufacturing industries. Information Systems Journal, 12(2), 121-152.

Camisón-Zornoza, C., Lapiedra-Alcamí, R., Segarra-Ciprés, M., \& Boronat-Navarro, M. (2004). A meta-analysis of innovation and organizational size. Organization Studies, 25(3), 331-361.

Cassiman, B., \& Golovko, E. (2011). Innovation and internationalization through exports. Journal of International Business Studies, 42, 56-75

Chen, Y., \& Barnes, S. (2007). Initial trust and online buyer Behaviour. Industrial Management \& Data Systems, 107(1), 21-36.

Chong, A.Y., Ooi, K., Lin, B., \& Tang, S. Y. (2009). Influence of interorganizational relationships on SMEs' e-business adoption. Internet Research, 19, 313-331.

Chong, W. K., Shafaghi, M., \& Tan, B. L. (2011). Development of a business-to-business critical success factors (B2B CSFs) framework for Chinese SMEs. Marketing Intelligence \& Planning, 29, 517-533.

Chung, H. (2012). Export market orientation, managerial ties, and performance. International Marketing Review, 29(4), 403-423.

Czuchry, A., Yasin, M., \& Robertson, L. (2002). Entrepreneurial e-commerce: Strategy and tactics. Information Strategy: The Executive's Journal, 18(2), 42-48.

Damanpour, F., \& Schneider, M. (2009). Characteristics of innovation and innovation adoption in public organizations: Assessing the role of managers. Journal of Public Administration Research and Theory, 19(1), 495-522.

Deshpande, R., Farley, J. U., \& Webster, Jr. F. (1993). Corporate culture, customer orientation, and innovativeness in Japanese firms: A quadrat analysis. Journal of Marketing, 57(1), 23-37. 
Dimitratos, Y., \& Dana, L. P. (2003). International entrepreneurship research: What scope for international business theories. Journal of International Entrepreneurship, 1(1), 31-42.

Edwards, L., Sanfilippo, M., \& Sundaram, A. (2018). Importing and firm export performance: New evidence from South Africa. South African Journal of Economics, 86(1), 79-95.

Eid, R., \& T rueman, M. (2004). Factors affecting the success of business-to-business international internet marketing (B-to-B IIM): An empirical study of UK companies. Industrial Management \& Data Systems, 104(1), 16-30.

Evans, P., \& Wurster, T. S. (2000). Blown to bits: How the new economics of information transforms strategy. Harvard Business School Press, Boston, USA.

Farhoomand, A., \& Lovelock, P. (2001). Global e-commerce, TEXT and CASES, Singapore.

Ghemawat, P. (2001). Distance still matters: The hard reality of global expansion. Harv Bus Rev, 79(8), $137-147$.

Gong, W. (2009). National culture and global diffusion of business to consumer e-commerce. National Culture and Global Diffusion, 16(1), 83-101.

Gonzalez, J., \& Chiagouris, L. (2006). Internet support companies: The impact of marketing orientation. Journal of Internet Banking and Commerce, 11(1).

Grandón, E., Nasco, S., \& Mykytn, P. (2011). Comparing theories to explain e-commerce adoption. Journal of Business Research, 64(3), 292-298.

Hair, J. F., William, C., Black, B., Babin, J., \& Rolph, E. (2010). Multivariate data analysis, Upper Saddle River, NJ: Prentice Hall.

Hajidimitriou, Y., \& Azaria, A. (2009). Internet and export marketing: Impact of internet use on export revenues of Greek SMEs. 35th EIBA Annual Conference - Proceedings, Porto Hart \& Banbury.

Hofstede, G. (2011). Dimensionalizing cultures: The Hofstede model in context. Online Readings in Psychology and Culture, 1-26.

Houdeloudi, Z., \& Hajidimitriou, Y. A. (2014). Success factors of internet use for exporting by Greek companies during the period of the financial crisis. MIBES Transactions International Journal, 8, 13-30.

Pei-Fang, Hsu., Kenneth, Kraemer, L., \& Debora, D. (2014). Determinants of e-business use in U.S. firms. International Journal of Electronic Commerce, 10(4), 9-45.

Hsu, P. F., Kraemer, K. L., \& Dunkle, D. (2006). Determinants of e-business use in US firms. International Journal of Electronic Commerce, 10(4), 9-45.

Jean, R. J. B., \& Sinkovics, R. R. (2010). Relationship learning and performance enhancement via advanced information technology: The case of Taiwanese dragon electronics firms. International Marketing Review, $27(2), 200-222$

Jensen, J. (2003). Issues facing SMEs in their adoption of electronic commerce, communication research forum, 1-2 October, Old Parliament House, Canberra, Australia.

Jeyaraj, A., Rottman, J., \& Lacity, M.J. (2006). A review of the predictors, linkages, and biases in IT innovation adoption research. Journal of Information Technology, 21(1), 1-23.

Ju, M., Murray, J. Y., Kotabe, M., \& Gao, G. Y. (2011). Reducing distributor opportunism in the export market: Effects of monitoring mechanisms, norm-based information exchange, and market orientation. Journal of World Business, 46, 487-496.

Kim, D. J., Ferrin, D. L., \& Rao, H. R. (2008). A trust-based consumer decision-making model in electronic commerce: The role of trust, perceived risk, and their antecedents. Decision Support Systems, 44, 544-564.

Kontinen, T., \& Ojala, A. (2010). The internationalization of family businesses: A review of extant research. Journal of Family Business Strategy, 97-107.

Kosan, S. V., \& Kabuya, F. I. (2014). An empirical analysis of determinants of Swaziland's export performance. International Journal of Sciences: Basic and Applied Research, 16(1), 197-212.

Kula, V., \& Tatotglu, E. (2003). An exploratory study of internet adoption by SMEs in an emerging market economy. European Business Review, 15(5), 324-333.

Lages, L. F., \& Montgomery, D. B. (2004). Export performance as an antecedent of export commitment and 
marketing strategy adaptation: Evidence from small and medium-sized exporters. European Journal of Marketing, 38(9/10), 1186-1214.

Lal, K. (2004). E-business and export behaviour: Evidence from Indian firms. World Development, 32(4), 505-517.

Leonidou, L. C., \& Barnes, B. R. (2010). Assessing the contribution of leading mainstream marketing journals to the international marketing discipline. International Marketing Review, 27(5), 491-518.

Liao, C. H., \& Tseng, P. H. (2010). Influential factors of VoIP adoption of top 500 export-import enterprises in Taiwan. Contemporary Management Research, 6(1), 11-28.

Ling, K. C., Daud, D. B., Piew, T. H., Keoy, K. H., \& Hassan, P. (2011). Perceived risk, perceived technology, online trust for the online purchase intention in Malaysia. International Journal of Business and Management, 6(6), 167-182.

Lituchy, T. R., \& Rail, A. (2000). Bed and breakfast, small inns, and the internet. The impact of technology on the globalization of small businesses. Journal of International Marketing, 8(2), 86-97.

Loane, S., \& Bell, J. (2006). Rapid internationalisation among entrepreneurial firms in Australia, Canada, Ireland and New Zealand. International Marketing Review, 23(5), 467- 485.

Lohrke, T., \& Frownfelter-Lohrke, C. (2006). SME internet use the internet as an information conduit: A transaction cost analysis model of US. International Small Business Journal, 24(2), 159.

Lu, V., \& Julian, C. (2008). The internet, strategy and performance: A study of Australian export market ventures. Journal of Global Marketing, 21(3), 231.

Lu, Y. B., Deng, Z. C., \& Yu, J. H. (2006). A study on evaluation items and its application for B2C e-commerce trust. Proceedings of the International Conference on Management Science and Engineering (ICMSE), Lille, France, 13-18.

Masa'deh, R., Alananzeh, O., Algudah, O., \& Tarhini, A. (2018). The effect of promotional mix on hotel performance during the political crisis in the Middle East. Journal of Hospitality and Tourism Technology, $9(1), 32-47$.

Mathews, S., \& Healy, M. (2007). The internet and information capability reduces perceived risk of internationalisation: An Australian SME perspective. International Journal of Organisational Behaviour, 12(1), 71-87.

Mathews, S., \& Healy, M. (2008). From garage to global: The internet and international market growth, an SME perspective. International Journal of Internet Marketing and Advertising, 4(2/3), 179-196.

Mathews, S., Healy, M. J., \& Wickramasekera, R. (2012). The internetalisation of information, knowledge and interaction components of the firm's internationalisationpocess. Journal of Marketing Management, 28(5-6), 733-754.

Matta, V., \& Moberg, C. (2006). The development of research agenda for RFID adoption and effectiveness in supply Chains. Issues in Information Systems, 7(2), 246-251.

Melewar, T. C., \& Smith, N. (2003). The internet revolution: Some global marketing implications. Marketing Intelligence \& Planning, 2(6), 363-369.

Moen, Ø., Madsen, T. K., \& Aspelund, A. (2008). The importance of the internet in international business-to-business markets. International Marketing Review, 25(5), 487.

Mondragon, A. E. C., Lyons, A. C., Michaelides, Z., \& Kehoe, D. F. (2006). Automotive supply chain models and technologies: A review of some latest developments. Journal of Enterprise Information Management, 19(5), 551-562.

Moodley, S. (2002). Connecting to global markets in the internet age: The case of South African wooden furniture producers. Development Southern Africa, 19(5), 641-658.

Moodley, S., \& Morris, M. (2004). Does e-commerce fulfil its promise for developing country (South African) garment export producers?. Oxford Development Studies, 32(2), 155-178.

Moon, B. J., \& Jain, S. (2007). Determinants and outcomes of internet marketing activities of exporting firms. Journal of Global Marketing, 20(4), 55-71.

Morgan-Thomas, A. (2009). Online activities and export performance of the smaller firm: A capability 
perspective. European Journal of International Management, 3(3), 266-285.

Morgan-Thomas, A., \& Bridgewater, S. (2004). Internet and exporting: Determinants of success in virtual export channels. International Marketing Review, 21(4/5), 393-408.

Mukherjee, A., \& Prithwiraj, N. (2007). Role of electronic trust in online retailing: A re-examination of the commitment-trust theory. European Journal of Marketing, 41(9).

Muriithi, P., Horner, D., \& Pemberton, L. (2016). Factors contributing to adoption and use of information and communication technologies within research collaborations in Kenya. Information Technology for Development, 22(1), 84-100.

Musteen, M., \& Datta, D. (2010). The influence of international networks on internationalization speed and performance: A study of Czech SMEs. Journal of World Business, 45, 197-205.

Mysen, T. (2013). Towards a framework for controls as determinants of export performance: A review and contradictory to the outward emphasis. European Business Review, 25(3), 224.

Nasco, S., Toledo, E., \& Mykytyn, Jr. (2008). Predicting electronic commerce adoption in Chilean SMEs. Journal of Business Research, 61(6), 697-705.

Obeidat, B., Tarhini, A., Masa'deh, R., \& Aqqad, N. (2017). The impact of intellectual capital on innovation via the mediating role of knowledge management: A structural equation modelling approach. International Journal of Knowledge Management Studies, 8(4), 273-298.

Osakwe, M., Chovancová, M., \& AguCan (2016). Micro-enterprises leverage on the adoption of corporate websites to bolster their brand visibility? Examining Salient Adoption Issues in Nigeria. Inf.Dev., 32(4), 904-919.

Poon, S., \& Swatman, P. M. C. (1997). Internet-based small business communications: Seven Australian case. Proceedings of the PACIS Conference, Brisbane, Australia.

Ramdani, B., Kawalek, P., \& Lorenzo, O. (2009). Knowledge management and enterprise systems adoption by SMEs: Predicting SMEs' adoption of enterprise systems. Journal of Enterprise Information Management, 22(1/2), 10-24.

Raymond, L. (2001). Determinants of web site implementation in small businesses. Internet Research: Electronic Networking Applications and Policy, 11(5), 411-422.

Roccapriore, D. (2000). Building IT for export exploration, Part II. Business and Economic Review, 46(3), 21-23.

Rodgers, S., Jin, Y., Rettie, H., \& Yoon, D. (2005). Internet motives of users in the United States, United Kingdom, Australia, and Korea. Journal of Interactive Advertising, 6, 61-67.

Rogers, E. M. (1995). Diffusion of innovations: Modifications of a model for telecommunications. Die Diffusion von Innovation in der Telecommunication. Berlin: Springer, 25-38.

Rosson, P. (2004). The internet and SME exporting: Canadian success stories. In H. Etemad (Ed.), International Entrepreneurship in Small and Medium Size Enterprises: Orientation, Environment and Strategy. Edward Elgar Publishing, 2004, in Press.

Samiee, S. (1998). Exporting and the internet: A conceptual perspective. International Marketing Review, 15(5), 413- 426.

Scupola, A. (2003). Government intervention in SMEs e-commerce adoption: An institutional approach. Association for Information Systems AIS Electronic Library (AISeL), Pacific Asia Conference on Information Systems (PACIS).

Shankar, V., \& Jeff, M. (2009). Internet and international marketing. Handbook of International Marketing, Masaki Kotabe and Christiaan Helsen, eds. Sage, 451-467.

Shannak, R., \& Obeidat, B. (2012). Culture and the implementation process of strategic decisions in Jordan. Journal of Management Research, 4(4), 257-281.

Song, H. (2003). E-services at FedEx. Communications of the ACM, 46 (6).

Strauss, J., \& Frost, R. (2002). E-marketing. Prentice Hall: New Jersey.

Tarhini, A., Mgbemena, C., \& Trab, MSA. (2015). User adoption of online banking in Nigeria: A qualitative study. Journal of Internet Banking and Commerce, 20(3), 1-8. 
Taylor, T., \& Owusu, E. D. E. (2012). Factors affecting internet and e-commerce adoption among small and medium-sized enterprise non-exporters: Case studies of Ghanaian handicraft exporters. European Journal of Business and Management, 4(13), 45-55.

Teo, T. S. H., \& Choo, W. Y. (2001). Assessing the impact of using the internet for competitive intelligence. Information and Management, 39(1), 67-83.

Tornatzky, L., \& Fleischer, M. (1990). The process of technology innovation. Lexington: Lexington Books.

Ueasangkomsatea, P. (2015). Adoption e-commerce for export market of small and medium enterprises in Thailand. Procedia-Social and Behavioral Sciences, 111-120.

Van Huy, L., Rowe, F., Truex, D., \& Huynh, M. Q. (2012). An empirical study of determinants of e-commerce adoption in SMEs in Vietnam: An economy in transition. Journal of Global Information Management, 20, 23-54.

Van, A., \& Cavaye, A. (1999). Factors affecting entry-level internet technology adoption by small business in Australia: An empirical study. Proceedings of 10th Australasian Conference on Information Systems, Wellington, NZ., 1105-1117.

Wresch, W. (2003). Initial e-commerce efforts in nine least developed countries: A review of national infrastructure, business approaches and product selection. Journal of Global Information Management, $11(2), 67-78$.

Wu, F., Mahajin, V., \& Balasubramanian, S. (2003). An analysis of e-business adoption and its impact of business performance. Journal of the Academy of Marketing Science, 31(4), 425-447.

Zhang, H., \& Okoroafor, S.C. (2013). An e-commerce key success factors framework for Chinese SME exporters. International Journal of Economics and Finance, 6(1), 129-137.

Zhu K., \& Kraemer, K. (2005). Post-adoption variations in usage and value of e-business by organizations: Cross-country evidence from the retail industry. Information Systems Research, 16(1) 61-84.

Zhu, L., Thatcher, S. M., \& Thatcher, M. E. (2014). Institutional environment for business-to-business (B2B) e-commerce usage: Toward an understanding in the Chinese context. Journal of Information Technology Case and Application Research, 16(3-4), 127-154.

Zou, S., Fang, E., \& Zhao, S. (2003). The effect of export marketing capabilities on export performance: An investigation of Chinese exporters. Journal of International Marketing, 11(4) 32-55.

\section{Copyrights}

Copyright for this article is retained by the author(s), with first publication rights granted to the journal.

This is an open-access article distributed under the terms and conditions of the Creative Commons Attribution license (http://creativecommons.org/licenses/by/4.0/). 